\title{
Post-Devonian movement on the Fredericton Fault and tectonic activity in the New Brunswick Platform, central New Brunswick, Canada
}

\author{
Adrian F. PARK ${ }^{*}$ And Steven J. Hinds \\ Geological Surveys Branch, Department of Energy and Resource Development, Fredericton, New Brunswick E3B 5H1, Canada \\ ${ }^{*}$ Corresponding Author: <adrian.park@gnb.ca>
}

Date received: 21 March 2018 Date accepted: 13 February 2019

\begin{abstract}
The Norumbega Fault system is traced from southern New England to Prince Edward Island, and its major strike-slip history is pre-Carboniferous. Carboniferous and later movements are less well constrained. Along the Fredericton Fault in western New Brunswick, offsets affect outcrops of Carboniferous strata in several ways. Revision of Carboniferous stratigraphy in this area using new miospore data and mapping of new exposures augmented by LiDAR imagery permits refinement of some of the post-Devonian movement history. The oldest post-Silurian unit recognized, the Longs Creek Formation, is fault-dissected and tightly folded, with faults and folds overlapped by the unconformity at the base of the upper Visean Shin Formation. The age of the Longs Creek Formation is uncertain and may be late Devonian to early Visean. Faults affecting the Shin Formation and Royal Road basalts are truncated by the unconformity at the base of the Bolsovian Minto Formation. Beneath this unconformity the presence of fault-bounded panels of vertical Langsettian strata (Boss Point and Deerwood formations) along the Fredericton Fault demonstrate late Visean to Serpukhovian, and post-Langsettian, preBolsovian (Duckmantian) movements. At least three phases of movement can be seen affecting the Minto Formation. All the movement phases along the Fredericton Fault appear to be right-lateral strike-slip, except for one phase of post-Bolsovian left-lateral displacement.
\end{abstract}

\section{RÉSUMÉ}

Le système de failles de Norumbega sétend du sud de la Nouvelle-Angleterre jusqu'à l'île-du-PrinceÉdouard, et son décrochement le plus important date du pré-Carbonifère. Les mouvements survenus durant le Carbonifère et ultérieurement ne sont pas aussi contraints. Le long de la faille de Fredericton dans l'ouest du Nouveau-Brunswick, des décalages influent sur les affleurements des strates du Carbonifère de plusieurs façons. La révision de la stratigraphie carbonifère dans cette région à l'aide de nouvelles données sur les miospores et la cartographie de nouvelles expositions, augmentées par l'imagerie par LiDAR, permet de mieux suivre l'histoire des mouvements post-dévoniens. La plus ancienne unité post-silurienne reconnue, la formation de Long Creek, est disséquée en failles et arbore des plissements serrés, avec des failles et des plis chevauchés par une discordance à la base de la formation de Shin, du Viséen supérieur. L’âge de la formation de Long Creek est incertain - celle-ci pourrait dater de la fin du Dévonien au début du Viséen. Les failles influant sur la formation de Shin et les basaltes de Royal Road sont tronquées par une discordance à la base de la formation de Minto, datant du Bolsovien. Sous cette discordance, la présence de panneaux faillés d'une strate verticale remontant au Langsettien (formations de Boss Point et de Deerwood) le long de la faille de Fredericton témoigne de mouvements du Viséen tardif au Serpoukhovien ainsi que de mouvements post-langettiens de la période pré-bolsovienne (duckmantienne). Au moins trois phases de mouvements influant sur la formation de Minto peuvent être dégagées. Toutes les phases de mouvements le long de la faille de Fredericton semblent associées à des décrochements latéraux du côté droit, à l'exception d'une phase de déplacement latéral vers la gauche durant la période post-bolsovienne.

[Traduit par la redaction]

\section{INTRODUCTION}

The Fredericton Fault in southwestern New Brunswick is part of the Norumbega Fault system mapped from New En- gland to the Gulf of St. Lawrence (Ludman and West 1999). It is one of several orogen-parallel major fault zones in the Appalachian orogen of New England and Maritime Canada (Waldron et al. 2015 and references therein, see Fig. 1). 


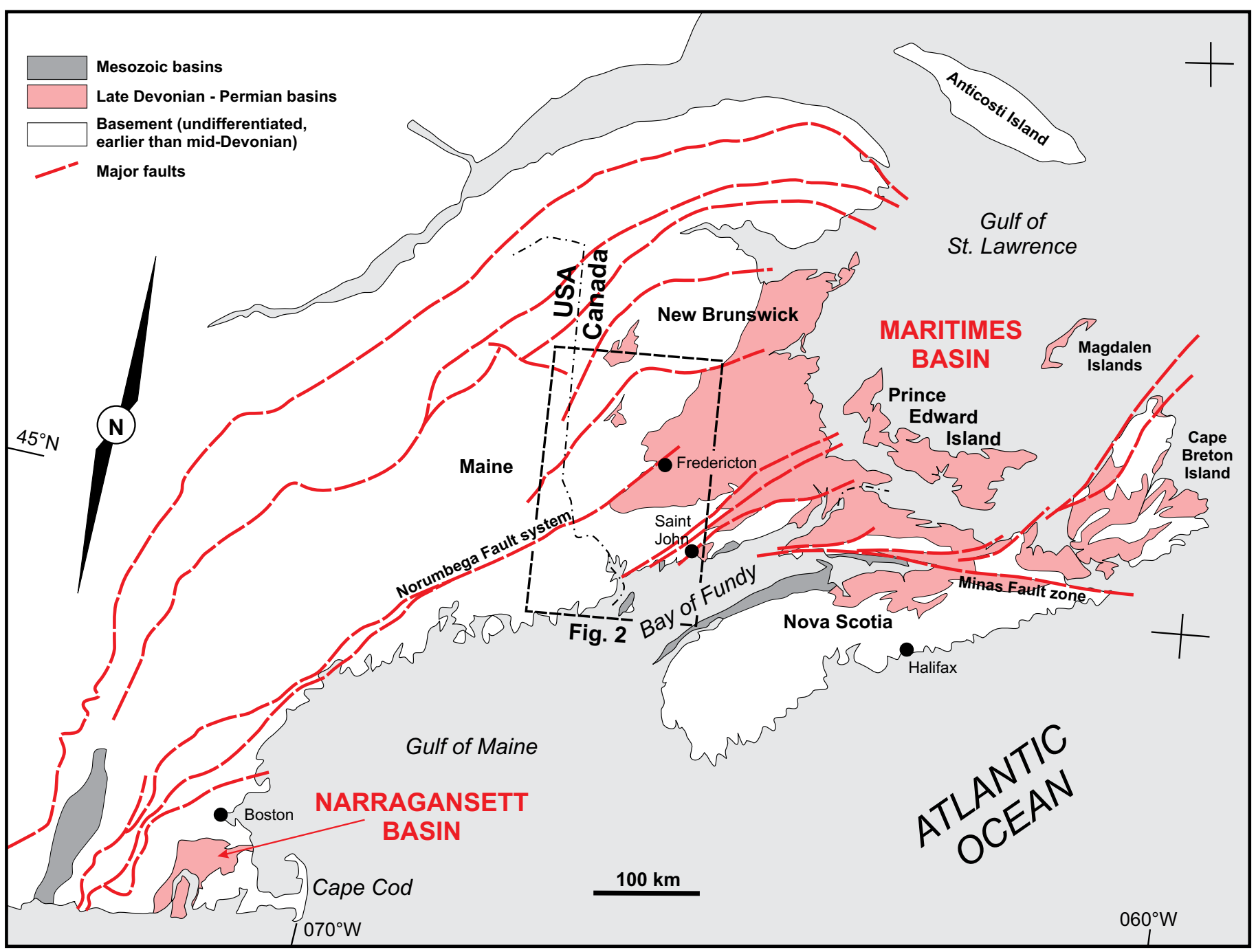

Figure 1. Generalized map of New England and Maritime Canada with the position of the main upper Paleozoic basins and major strike-slip faults in the Appalachian orogen (after Waldron et al. 2015).

The Fredericton Fault is part of this system in western New Brunswick, seen at surface into the Fredericton area (Fig. 2). To the northeast of Fredericton, the fault disappears beneath the Pennsylvanian cover of the central New Brunswick platform. North-east of this area the Fredericton fault can be traced as a geophysical feature as far east as Prince Edward Island (Durling and Marillier 1990, Fig. 1).

A history of right-lateral strike-slip motion on the Norumbega system, including the Fredericton Fault, has been extensively documented, and constraints on timing suggest most of this history occurred during the earlier Paleozoic (primarily Devonian) (Ludman and West 1999; Ludman et al. 1999; Ludman et al. 2017; Park and Whitehead 2003). Subsequent reactivation of the fault system is locally apparent (e.g., Wang and Ludman 2002; West and Roden-Tice
2003), which is a feature common among the orogen-parallel faults in the northern Appalachians (Goldstein 1989). Details of the timing of reactivation along most portions of the Norumbega system have remained conjectural due largely to the absence of well-dated post-Devonian strata (Ludman et al. 1999; West et al. 2008).

A series of 'molasse'-filled basin remnants occur in Maine, but the age of the red conglomerate, breccia and coarse sandstone strata filling them is poorly constrained (Wang and Ludman 2002). These fault-bounded and elongate basin remnants extend into southwestern New Brunswick, where they have been correlated lithostratigraphically with the late Visean-Serpukhovian Mabou Group and more specifically the red Shin Formation that occurs widely beneath Pennsylvanian strata on the central New Brunswick platform (Fyffe

Figure 2. (next page) Simplified geological map of southwestern New Brunswick and adjacent parts of Maine showing Carboniferous units and major strike-slip faults (after Smith 2005). 


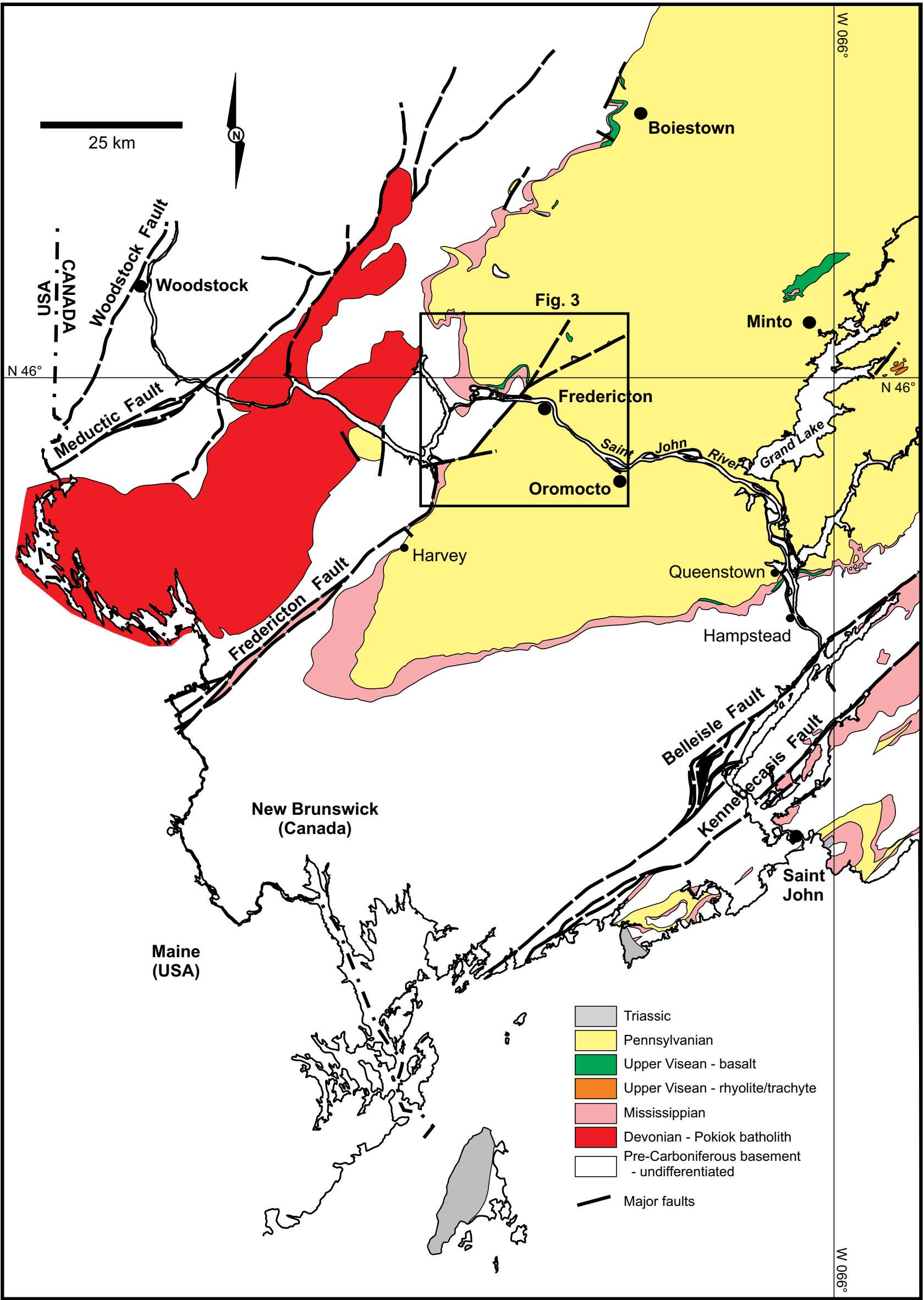


et al. 2005; McLeod et al. 2005; St. Peter and Fyffe 2005, Fig. 2).

A substantial part of the problem regarding post-Devonian activity along the Fredericton Fault arises from: (1) poor outcrop, (2) poor constraints on the stratigraphy of the Carboniferous sequence in southwestern New Brunswick, and (3) the problem of distinguishing between red bed sequences that make up much of the Carboniferous in New Brunswick as a whole. This paper deals with roughly $50 \mathrm{~km}$ segment of Fredericton Fault centred on the Fredericton area (Figs $2,3)$. Recent field mapping was aided by new construction along Highways 2 and 8 since the late 1990s and the recent availability of LiDAR imagery (New Brunswick Department of Natural Resources 2016). Additionally, recently expanded miospore analysis has improved resolution of the Carboniferous stratigraphy in this area. This, in turn, has led to new understanding of the history of reactivation of the Fredericton Fault from Visean to late Pennsylvanian time.

\section{STRATIGRAPHIC BACKGROUND}

Carboniferous stratigraphy in the New Brunswick portion of the Maritimes Basin (Fig. 1) consists of five depositional cycles recognized in the southeastern area of the province, which are assigned to six groups: from oldest to youngest, the Late Devonian-Mississippian Horton, Sussex, Windsor, and Mabou groups, and the Pennsylvanian Cumberland and Pictou groups (summarized in St. Peter and Johnson 2009, and references therein, Fig. 4). These groups are separated by unconformities that can be mapped across the southern, central and eastern part of the province. Most of the Carboniferous sequence in New Brunswick is dominated by coarse to fine siliciclastic red beds, with exceptions of: (a) a lacustrine oil shale interval in the Tournaisian Horton Group (Albert Formation), (b) a marine carbonateevaporite interval in the Visean Windsor Group, and (c) grey coal-bearing intervals in the Pennsylvanian Cumberland and Pictou groups. Much of the correlation has relied historically on lithostratigraphic assignment into the above groups based mostly on stratigraphy in Nova Scotia, except for the Sussex Group, which was defined in New Brunswick. Biostratigraphic correlation is only possible on the marine zone fossils of the carbonate and evaporite sequences of the Windsor Group, with the remainder relying on miospores (St. Peter and Johnson 2009).

The rocks assigned to the Mabou Group have been particularly problematic. South of Moncton to the Nova Scotia border, a red-bed sequence lying between the carbonateevaporite of the Windsor Group and below the grey coal-bearing Cumberland Group is partly correlative with the Mabou Group of the Cumberland basin in Nova Scotia (St. Peter and Johnson 2009; Waldron et al. 2013; Craggs et al. 2015). In much of New Brunswick, the Mabou Group designation becomes more difficult and has been generalized as a red bed sequence occurring above the carbonate-evaporite units of the Windsor Group and below Pennsylvanian grey intervals and their basal unconformity. On the central New
Brunswick platform, the depositional environment is more restricted and the Mabou Group correlation becomes most questionable (see for instance Jutras et al. 2007).

In the Fredericton area, the Mabou Group comprises an upward-fining red siliciclastic sequence ranging from coarse conglomerate to siltstone and claystone assigned to the Shin Formation (Fig. 2). Locally, the Shin Formation has distinct cyclicity, with the top of each cycle marked by a paleosol with rootlet beds with, or without caliche zones (van de Poll 1972). Throughout much of the platform, especially from Boiestown, through the Fredericton area, to Queenstown and Hampstead (Fig. 2), this sequence rests with angular unconformity on the Silurian sedimentary rocks of the Fredericton Trough (Kingsclear Group), and middle Devonian granitoid rocks intruding the Silurian sequence, the Devonian Piskahegan Group and the CambrianOrdovician Annidale Group (St. Peter and Fyffe 2005; McLeod et al. 2005; Smith and Fyffe 2006a, b, c; Smith 2007). Near Queenstown and Hampstead (Fig. 2), a thin carbonate unit underlies the red beds: locally a calcrete (with jasperchalcedony) developed on the underlying basement (Johnson and Jutras 2004), or a bioclastic limestone with calcareous sandstone correlated with the Parleeville Formation of the Windsor Group further to the southeast (McLeod et al. 2005, Fig. 2).

In the Fredericton area, and sporadically along the western edge of the central New Brunswick platform around from Stanley, to Boiestown (Fig. 3), the Shin Formation is topped by a volcanic sequence which is mainly basaltic (Royal Road basalts), (Ball et al. 1981; Fyffe and Barr 1986; Smith and Fyffe 2006a, b, Figs 2, 3). A thick basalt unit lies near the top of the Shin Formation at Queenstown in the south, and within inliers around Minto and Chipman (Fig. 2). The volcanic sequences of the Hardwood Ridge basalt overlie a red conglomerate sequence of the Newcastle Creek Formation or rest directly on Silurian basement (St. Peter 1997; Smith and Fyffe 2006c; Smith 2007, Fig. 3). The trachyte-rhyolite units at Cumberland Hill is assumed to lie directly on the same basement (Fig. 3, Smith and Fyffe 2006c; Smith 2007; Gray et al. 2010). The volcanic intervals in the Minto and Chipman areas were once partially correlated with the late Devonian Piskahegan Group (Ball et al. 1981), then reinterpreted as ranging in age from the upper part of the Shin Formation (and therefore crudely 'Namurian') to being late Pennsylvanian and intercalated with the Pictou Group (see for instance Fyffe and Barr 1986). Subsequent remapping of the area elucidated a common relationship to the Newcastle Creek Formation and included all the volcanic units within a stratigraphy equivalent to the Shin Formation. This relationship is corroborated by an unpublished $\mathrm{U}-\mathrm{Pb}$ zircon age of $335 \pm 2 \mathrm{Ma}$ from the Cumberland Hill rhyolite (St. Peter, cited in Smith 2007). This age determination is the same, within error, as a U-Pb zircon age for a rhyolitic ash bed within the Upperton Formation (Windsor Group) evaporitic rocks (338 $\pm 7 \mathrm{Ma}$, MacFarlane et al. 2015, Fig. 4) and the lower of two ash beds beneath the Hardwood Ridge basalts (Jutras et al. 2018). Not only does this strongly imply correlation 


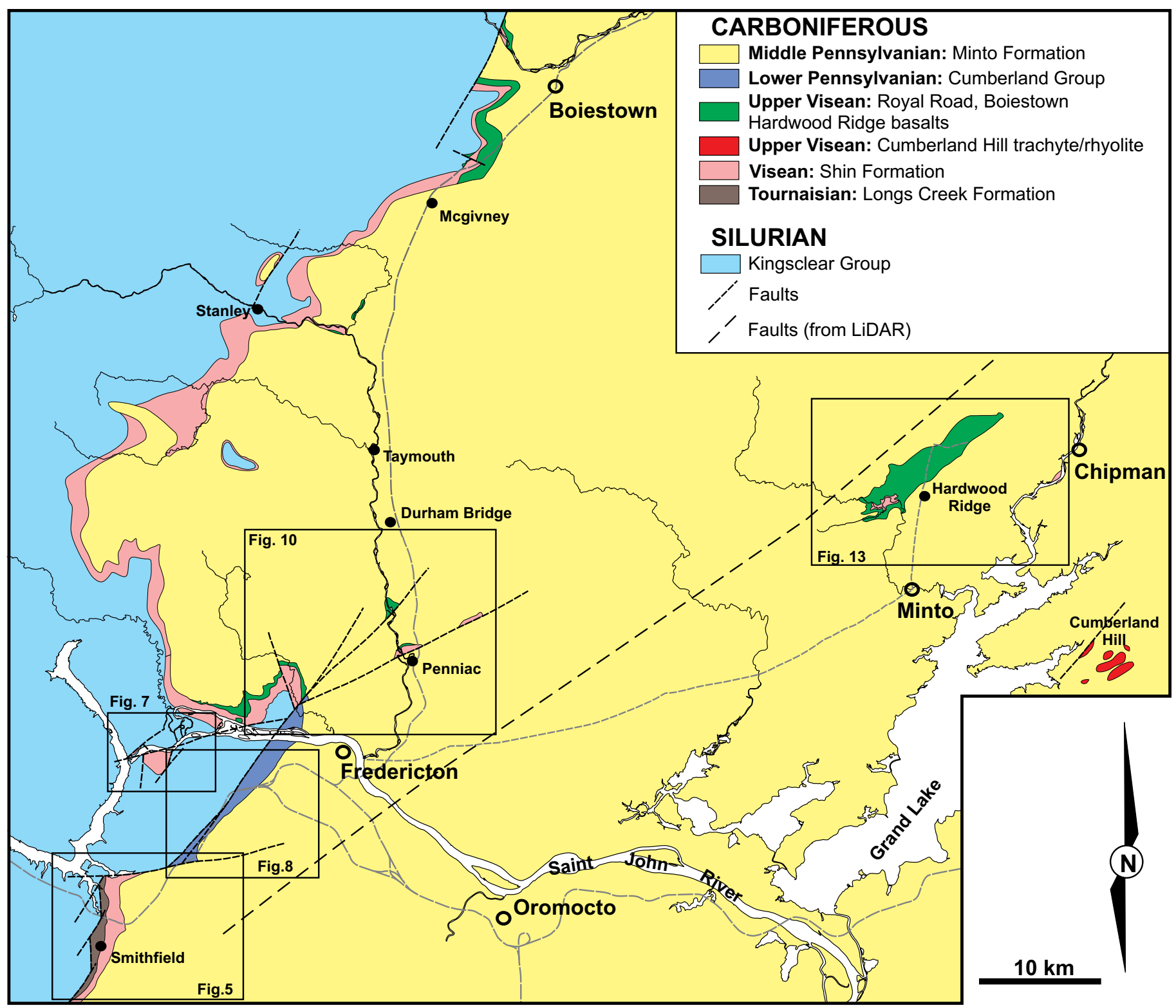

Figure 3. Geological map of the Fredericton-Boiestown-Chipman area, New Brunswick with distribution of Carboniferous units (after Smith and Fyffe 2006a, b, c; Smith 2007; St. Peter and Fyffe 2005, modified after this study).

of the Shin Formation with the Windsor Group, rather than the Mabou Group (at least time equivalents), but also places the sequence into the Asbian-Brigantian stages of the late Visean. This revised stratigraphy has more in common with the Percé Group suggested by Jutras et al. (2007, see also Jutras and Prichonnet 2005), and is consistent with the Parleeville Formation correlation with the carbonates at the base of the Shin Formation in the Hampstead area (McLeod et al. 2005). Rather than being scattered through 'Namurian' to 'Westphalian C or D', the volcanic rocks are all within the same Upper Visean interval, and correlate with those of the Magdalen Islands in the Gulf of St. Lawrence, and in the subsurface of Prince Edward Island (Fig. 1, Brisebois 1981; Barr et al. 1985; Fyffe and Barr 1986; La Flèche et al. 1998; Giles and Utting 1999; Giles 2008).
Extending from the Fredericton area to Minto and Chipman the red-beds of the Shin Formation and the associated volcanic rocks are overlain by a grey to minor red siliciclastic sequence with coal beds (Figs 2, 3). The Minto coalfield is North America's oldest mined field (Martin 2003) and is contained within the Minto Formation. Miospores analyzed during the Carboniferous drilling project (Ball et al. 1981) imply the entire sequence around Minto, from the unconformity above the volcanic rocks upwards, belongs to the late Duckmantian or Bolsovian stages (Westphalian B-C, uppermost Bashkirian/lower Moscovian). This is consistent with analysis of macroflora, and of the Minto coals themselves (Dyer 1926; Muller 1951; Kalkreuth et al. 2000). However, in the Fredericton area older Pennsylvanian miospores were reported from two locations identified as Westphalian A, 


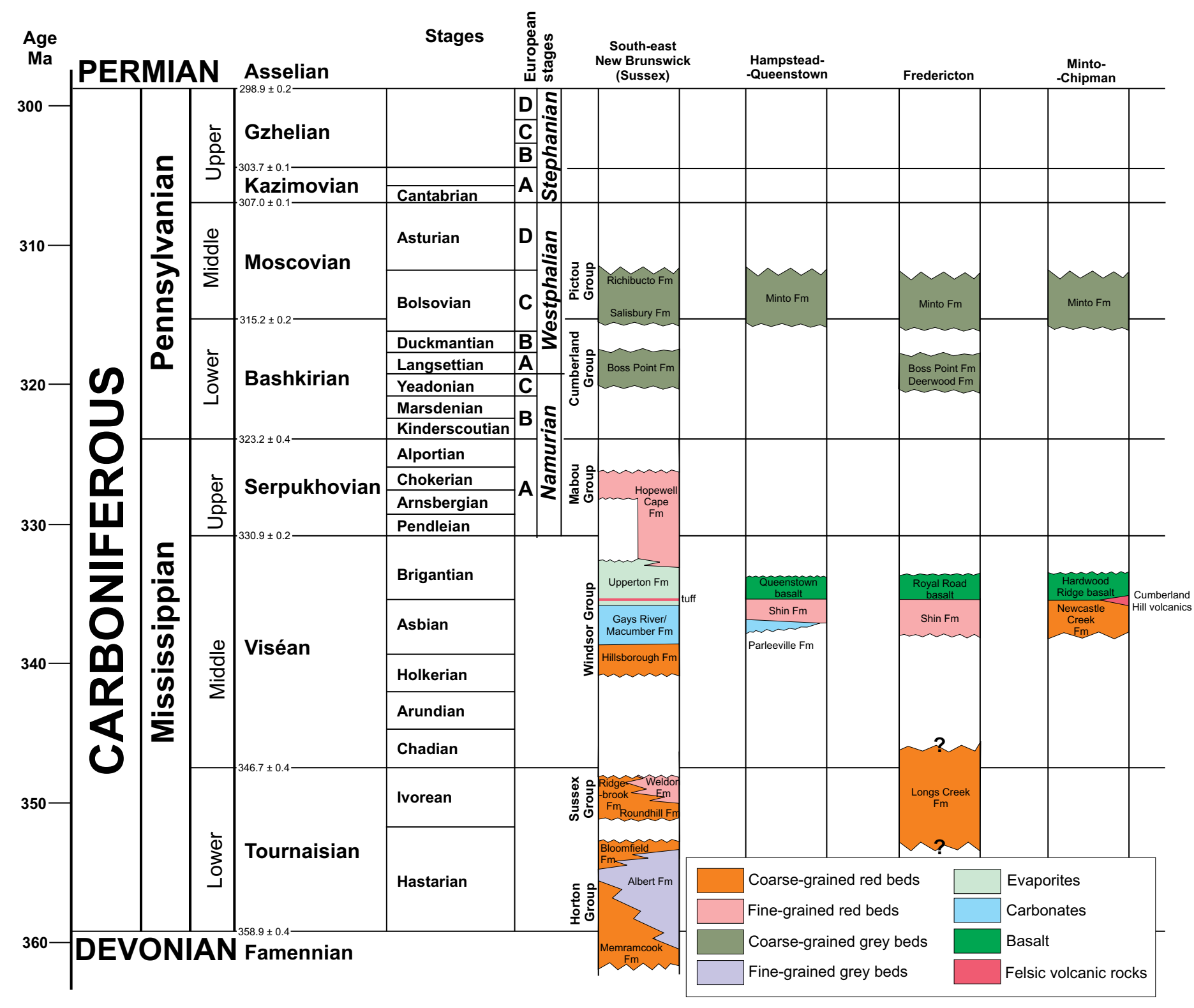

Figure 4. Stratigraphy of the upper Paleozoic rocks of central New Brunswick comparing the incomplete succession on the central platform with the Sussex area (modified after St. Peter and Johnson 2009; Jutras et al. 2005 and this study).

(Langsettian) which lie beneath the coal seam-bearing sequence and above the Royal Road basalt (Barss 1983). This suggested the presence of the Boss Point Formation of the Cumberland Group within the Fredericton area, while everything else was included in the Pictou Group. In the remapping by St. Peter and Fyffe (2005), all the Pennsylvanian stratigraphy was simplified as the Minto Formation, with the 'Hurley Creek Formation' reduced to Member status and 'Sunbury Creek Formation' abandoned (Smith and Fyffe 2006a, b, c; Smith 2007). The Minto Formation included all the Pictou Group strata in the Fredericton area, with pre-Bolsovian miospores attributed to reworked material.

Timing of the interaction of the Fredericton Fault movement and these Carboniferous units is dependent on the confirmation of the existence of Pennsylvanian rocks older than the Bolsovian Minto Formation (Fig.4) and the validity of assigning the entire underlying red bed sequences to the Shin Formation. The older movements of the Fredericton Fault are well-constrained by the deposition of WenlockLudlow age sediments in the Fredericton Trough, the intrusion of a lamprophyre dike swarm associated with the early phases of the Pokiok batholith intrusion across the PridoliLochkovian boundary, and as young as Emsian (SilurianDevonian, 402-420 Ma, see Bevier and Whalen 1990; Whalen 1993; Leonard et al. 2006). Similar constraints are provided by offsets and foliation of dated granitoids in eastern Maine (the Middle Devonian Bottle Lake and Delbois plutons, Wang and Ludman 2002). Carboniferous and later fault movement is implied by: (1) the interaction of the Fredericton Fault and east-west faults with 'Shin Formation' 
and Minto Formation around Longs Creek, Mazerolle Settlement, Hanwell and Mactaquac areas, (2) the apparent fault juxtaposition of Royal Road basalt with Minto Formation near Royal Road immediately northwest of Fredericton, and (3) possible faults associated with the Hardwood Ridge inlier north of Minto and other inliers along the Nashwaak valley and the route of Highway 8 (Fig. 3).

\section{STRUCTURAL ANALYSIS OF THE FREDERICTON FAULT}

The detailed post-Devonian stratigraphy near the Fredericton fault in southwestern New Brunswick outlined above and shown in Figure 4 provide a context for interpretations of movements along this fault. The sections that follow provide detailed accounts of Fredericton fault displacements in specific areas, generally progressing from southwest to northeast along the fault.

\section{Smithfield to Mazerolle Settlement and Longs Creek (Fig.5)}

A narrow belt of red beds, predominantly conglomerate and sandstone, occur along the inlet south of Mazerolle Settlement (an inlet of the Mactaquac head pond), and continue south along the valley of the South Branch of Longs Creek past the villages of Newmarket and Smithfield to Harvey (St. Peter and Fyffe 2005, Fig. 5). New outcrops occur along Highway 2, and in recent subdivision developments between Highway 2 and Longs Creek itself. Between Smithfield and Longs Creek inlet on the Mactaquac head-pond, the belt is bounded to the west by N-S and NE-SW trending faults, with the latter truncating the former (St. Peter and Fyffe 2005). The eastern side of the belt is defined by the outcrop representing the base of the Minto Formation which dips gently eastward and forms the scarp of Porcupine Mountain (Fig. 5). This basal contact is inferred to be an angular unconformity.

Two red bed sequences that are separated by an angular unconformity have been identified in new outcrops along Highway 2, recently developed subdivisions between Highway 2 and Longs Creek inlet, and older outcrops along the South Branch Longs Creek and its tributaries (Fig. 5). The older unit is herein named Longs Creek Formation (see Appendix), while the upper unit is the Shin Formation. In outcrops on Highway 2 and the new subdivisions to the north, the Longs Creek Formation is a pebble to boulder conglomerate with sandstone to siltstone stringers and lenticular bodies. The conglomerate is generally matrix-supported, but locally clast-supported, red-brown in colour overall, though locally greenish. Clasts are predominantly granite (recognizably derived from the Pokiok batholith), grey sandstone and slate from the Silurian Kingsclear Group, vein quartz and basalt. The unit is strongly deformed in upright open to tight folds, and where it impinges on the N-S and NE-SW trending fault, is extensively sheared (Fig 6).
The age of the Longs Creek Formation is problematic. Greyish silty layers sampled for miospores yielded nothing (Dolby 2016). The presence of clasts of the Pokiok granite and truncation by the base of the Shin Formation (assumed to be upper Visean) provide the only constraints between middle Devonian and middle Visean. The deformation of the Longs Creek Formation and the N-S and NE-SW faults that cut it must also predate deposition of the Shin Formation. The Mazerolle Settlement Fault offsets the Minto Formation and is clearly a later structure.

The younger red bed sequences of the Shin Formation are best exposed in an old gravel pit north of the new subdivisions, along the South Branch of Longs Creek, and sporadically along the road at the foot of the Porcupine Mountain scarp (Fig 5). This is an upward-fining sequence of redbrown siliciclastic rocks ranging from pebble or cobble conglomerate through sandstone to siltstone, with scattered layers of caliche nodules that are typical of the Shin Formation. The unit is not notably deformed and folds are restricted to open and gentle warping, with most the package dipping at $10-15^{\circ} \mathrm{E}$ or SE beneath the overlying Minto Formation. The N-S and NE-SW trending faults that are involved in the strong deformation of the older Longs Creek Formation do not appear to affect or offset this unit.

The Shin Formation is overlain at a low-angle unconformity by the Minto Formation and the latter is best exposed along Highway 2 where the lowermost $50 \mathrm{~m}$ consists of grey to brown tabular pebble to cobble conglomerate layers with fossil $\log$ horizons (Lepidodendron, Sigillaria and Calamites), interfingered with coarse feldspathic sandstone containing abundant plant debris. The individual tabular bodies are up to $5 \mathrm{~m}$ thick, generally separated by dark grey shale, the top of which is marked by leached zones (probable paleosols) and intermittent thin coal seams. The base of some of the tabular conglomerate-sandstone bodies on these shale layers show large-scale loading structures and rheoplasts (ball and flame structures with a wavelength around $1 \mathrm{~m}$ are typical). Bedding generally dips shallowly $\left(<10^{\circ}\right)$ to the east along the unconformable lower contact. Approximately $50 \mathrm{~m}$ up sequence, the coarse siliciclastic units are overlain by a siltstoneclaystone interval some $30 \mathrm{~m}$ thick, with thin sheet-like sandstone bodies, caliche layers, paleosols with rootlets, and Stigmaria in growth position and intermittent coal seams (up to $15 \mathrm{~cm}$ thick). This predominantly red interval also contains coarse brown sandstone-pebble conglomerate bodies occupying down-cutting channels. This interval is in turn overlain by more tabular grey-brown sandstones with lenticular conglomerate bodies containing abundant logs and finer plant debris. This is the unit that hosts the Hanwell uranium showing (St. Peter and Fyffe 2005) which involves mineralized logs and plant debris. From outcrop miospores collected mainly around Minto itself, the age of the Minto Formation is constrained to be Bolsovian (Hacquebard and Barss 1970; Kalkreuth et al. 2000).

The Mazerolle Settlement Fault is nowhere exposed, but the linear feature associated with the fault is clearly imaged in LiDAR (Fig. 5). The fault runs beneath the inlet south of 

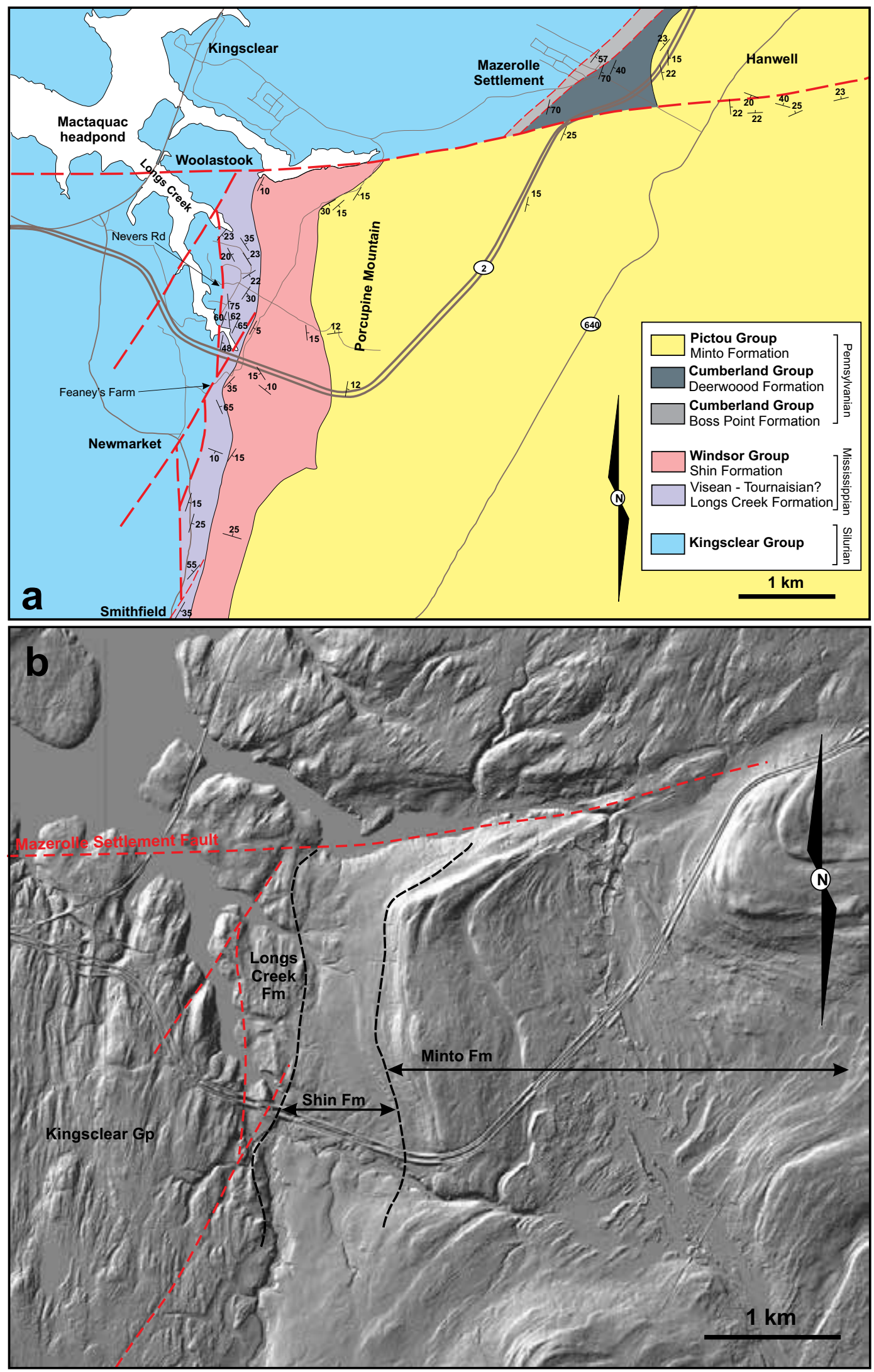

Figure 5. (a) Geological map of the Mazerolle Settlement to Smithfield area southwest of Fredericton incorporating the revisions from this study and from St. Peter and Fyffe (2005). Miospore data from Dolby (2016). (b) LiDAR image of the area shown in a. (note slightly different scale and boundaries) highlighting features used to define the Longs Creek and Shin formations. LiDAR image from New Brunswick Department of Natural Resources (2016). 

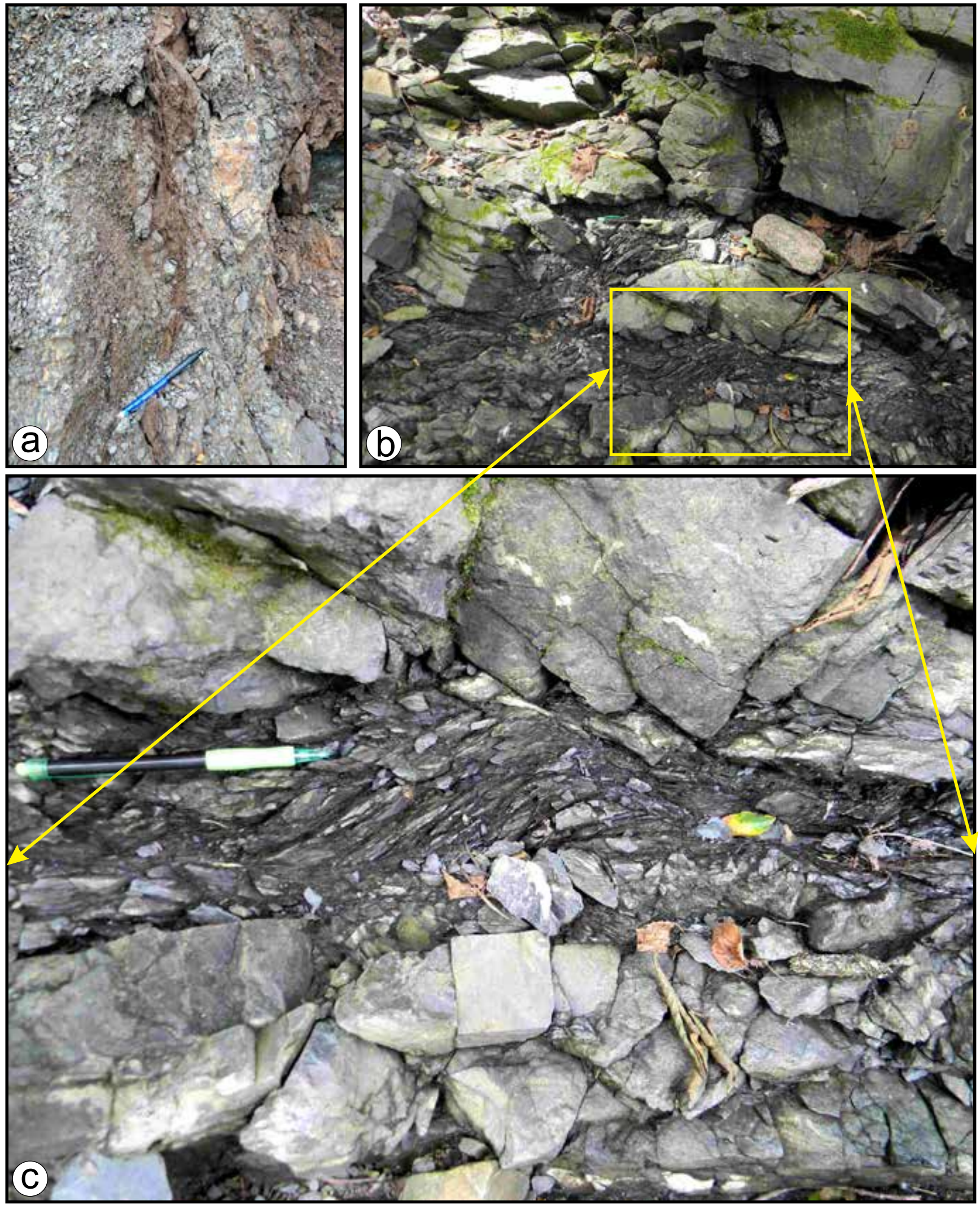

Figure 6. (a) Deformed conglomerate from the Longs Creek Formation with a disrupted layer of red-brown siltstone. Outcrop surface is vertical and movement indicators show left-hand (east) down in dip-slip. Nevers Road (see Figure 5b) GPS $\mathrm{N} 45.847^{\circ} \mathrm{W} 066.900^{\circ}$. (b) Fault-damaged zone in Silurian grey sandstone and shale (Kingsclear Group), surface is horizontal; creek bed near Feaney's Farm (see Figure 5b), Newmarket (GPS N $45.833^{\circ}$ W $066.902^{\circ}$ ). (c) Detail from b. showing sandstone 'knocker' and sigmoidal fabric in shale. Surface is horizontal, movement sense is top-to-right. 
Mazerolle Settlement, and truncates the Longs Creek and Shin formations. To the east, this fault offsets the base of the Minto Formation before it merges with a zone of folded Minto Formation in the south end of Hanwell (adjacent to the Hanwell uranium showing). The single expression of the Mazerolle Settlement Fault appears to disperse into a group of splays whose effect dies out eastward. The apparent lateral offset of the base of the Minto Formation, and the reddened interval across this fault is a topographic effect in shallowly dipping beds. Structural features in the Silurian rocks to the west show little or no strike-slip offset across this fault. A normal fault with the south-side down and an offset of some $50 \mathrm{~m}$ would account for the observed outcrop pattern. Minor normal faults seen in roadside outcrop near Hanwell village share this trend and show south-side down movement affecting the Minto Formation support this interpretation.

The more important structures in this area are the N-S and NE-SW trending fault sets that define the western edge of the outcrop of Longs Creek Formation against the Silurian basement. This N-S trending set is exposed in temporary outcrops at several locations in the new subdivisions north of Highway 2. Deformation in very steeply dipping conglomerate with siltstone/shale stringers consistently shows vertical dip-slip motion on east-side-down normal faults (Fig. 6a). The NE-SW fault set that cuts these normal faults runs parallel to a major structural grain in the underlying Silurian Kingsclear Group, clearly seen in LiDAR images and reported in older mapping (see St. Peter and Fyffe 2005, also Park and Whitehead 2003). As the Kingsclear Group is characterized by tight to overtightened chevron folds with breakout minor faults, distinguishing these Silurian features from those associated with the NE-SW fault set can be difficult. In a tributary of South Branch Longs Creek at Feaney's Farm east of Newmarket (see Fig. 5a) some 100 m of outcrop follows the Longs Creek Formation-Silurian contact and both units are extensively deformed in a damage zone at least $4 \mathrm{~m}$ wide along a fault. Sigmoidal fabrics, S-C fabrics and asymmetric sandstone knockers in deformed Silurian sandstone-shale demonstrate a right-lateral strike-slip motion along these faults, consistent with the offset of outcrop (Figs. 6b, c).

\section{Mactaquac (Fig.7)}

Red beds of the Shin Formation occur in outcrops north and south of the Saint John River immediately downstream of the Mactaquac hydro-electric dam and power station (St. Peter and Fyffe 2005, Fig. 7). Mapping undertaken prior to dam construction during the 1940s (Mackenzie 1946) showed this unit outcropping along both river banks and the creek through the Kingsclear Reserve at French Village (Fig.7). The Shin Formation was shown to be an upward-fining red bed sequence ranging from red-brown cobble conglomerate to red siltstone-claystone with calcareous nodules and layers. This sequence is capped by a sandstone unit correlated with the Minto Formation (St. Peter and Fyffe 2005).

Much of the river bank outcrop along the Saint John River below the dam is now buried by bank engineering work, but the basal coarse conglomerate is still visible on the south bank east of French Village (Fig.7). A red-brown or greengrey cobble conglomerate with caliche concretions, fines upward into red-brown and then red sandstone. The same sequence is seen in relatively new road cuts inland east of French Village, with more than one cycle evident, though upper cycles do not begin with conglomerate as coarsegrained as that seen at the base, and the topmost cycle commences with coarse sandstone. Caliche nodules are found throughout the sequence, but in the finer siltstone-claystone intervals they form distinct layers of nodular calcareous material resembling nodular limestone.

The topmost cycle of the Shin Formation terminates in outcrop as a coarse red-brown sandstone like those seen further down the stratigraphic sequence. This is the unit that was previously correlated with the Minto Formation on the 1:50 000 map sheet (St. Peter and Fyffe 2005). In outcrop at an excavation north of the old Highway 2, there is no evidence of an angular break below this sandstone. The sandstone is as red-brown as the other comparable units in this sequence, and contains caliche nodules. There is no reason to separate this sandstone package from the rest of the Shin Formation in this outlier, and consequently we suggest there is no recognizable Minto Formation here (Fig. 7).

In the outlier south of the river, the Shin Formation unconformably rests on folded strata of the Silurian Kingsclear Group, and the grey sandstone from this unit dominates the clast population in the overlying conglomerates. The unconformable relationship is also heavily modified by minor faults with both N-S and NE-SW orientations. Movement on these structures is no more than a few metres and they represent a minor reactivation of features forming the structural grain in the underlying Silurian rocks. These minor structures are not associated with the extensive deformation observed south of Mazerolle Settlement (Fig.5).

A series of E-W trending faults lie beneath the Saint John River, running through the gorge where the dam is sited, and outcrop on the north bank, where they bound an enclave of Shin Formation seen in the access road above the hydro-electric plant (Fig. 7). A coarse breccia-conglomerate (cobble) with caliche nodules rests with marked unconformity on Silurian sandstone and slate - the topmost metre of which being progressively reddened toward the contact. Two to three metres further up section, the conglomerate grades into sandstone with layers of caliche nodules. Inland of the gorge, this enclave is bound by an E-W trending fault whose gouge zone is exposed in creeks above the access road. This is one of the E-W faults showing south-side down normal motion. The faults below the river bed must show the same movement sense to account for the extensive outcrop of the Shin Formation south of the river.

\section{Trans-Canada Highway: Mazerolle Settlement to Fredericton (Fig.8)}

Construction of the Trans-Canada Highway (Highway 2) 


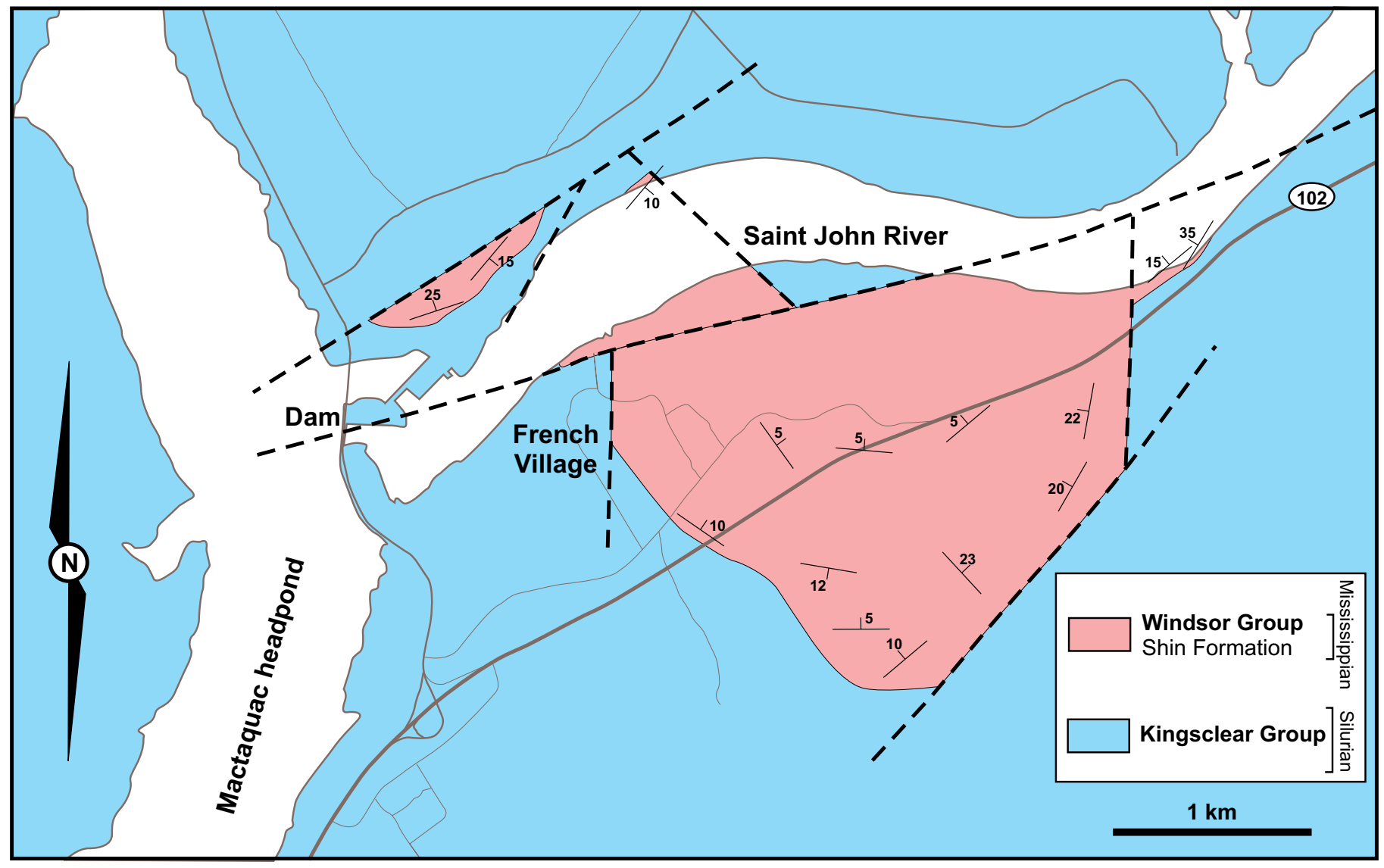

Figure 7. Geological map showing distribution of Shin Formation and faults east of the Mactaquac dam on the Saint John River incorporating data from Mackenzie (1946), St. Peter and Fyffe (2005), and this study.

as part of a Fredericton by-pass in 1998 created extensive new outcrop across the trend of the Fredericton Fault, exposing both Carboniferous and underlying Silurian units (Fig. 8). The fault itself was exposed during construction at the Deerwood Drive overpass (Park and Whitehead 2003), while to the SW extensive exposure along the CarboniferousSilurian contact revealed a more ambiguous relationship. Steeply dipping (generally $>75^{\circ}$ ) and locally overturned strata previously assigned to the Minto Formation are exposed from the truck weigh-scale SW of Deerwood Drive to a point $3 \mathrm{~km}$ to the SW (Fig 8). The Minto Formation here consists of grey-brown coarse feldspathic sandstone with lenticular conglomerate bodies and abundant logs and plant debris. During construction the basal contact with Silurian sandstone-shale was visible at the SW end of the truck weigh-scale off-ramp. The contact was seen to be a paleosol developed on the Silurian rocks, also dipping vertically, like the conglomerate-sandstone still exposed along the Highway 2 ditch. Prior to construction, this contact was mapped through badly exposed woodland as the trace of the Fredericton Fault, but mapping during construction suggested the fault itself lay to the southeast of the highway, either cutting Minto Formation or buried beneath it. A large fault north of the truck-scale running from the Deerwood Drive overpass to Mazerolle Settlement forming the true northern edge of Pennsylvanian outcrop is only clear on LiDAR images, though its presence has been confirmed in outcrop north of Highway 2 (Figs. 8, 9a, b).

Near Mazerolle Settlement (Fig. 8), two steeply dipping panels of sandstone are fault-bounded between the Silurian rocks and the shallow-dipping Minto Formation exposed on Highway 2 east of Longs Creek but north of the Mazerolle Settlement Fault. The western panel consists of dark grey coarse- to medium-grained sandstone with minor conglomerate lenses fining upward into a grey siltstone with dark shale partings. The sandstone is heavily indurated and harder than typical sandstone of the Minto Formation, and contains sparse plant debris, which distinguishes it from the Silurian Kingsclear Group (whose shales also carry a distinct slaty cleavage). One miospore locality (Barss 1983) just north of Mazerolle Settlement contained distinctive Langsettian (Westphalian A) stage spores. This implies a Cumberland Group affinity, and the unit has some lithological characteristics in common with the Boss Point Formation within this group. This panel can be traced through the woods along the northeast side of Highway 2 as far to the northeast at the truck weigh-scale (Fig. 8). At this point, the panel seems to pinch out between two faults that are clearly seen as linear features on LiDAR images (Fig 8). The western contact of this Boss Point Formation panel with the Silurian 

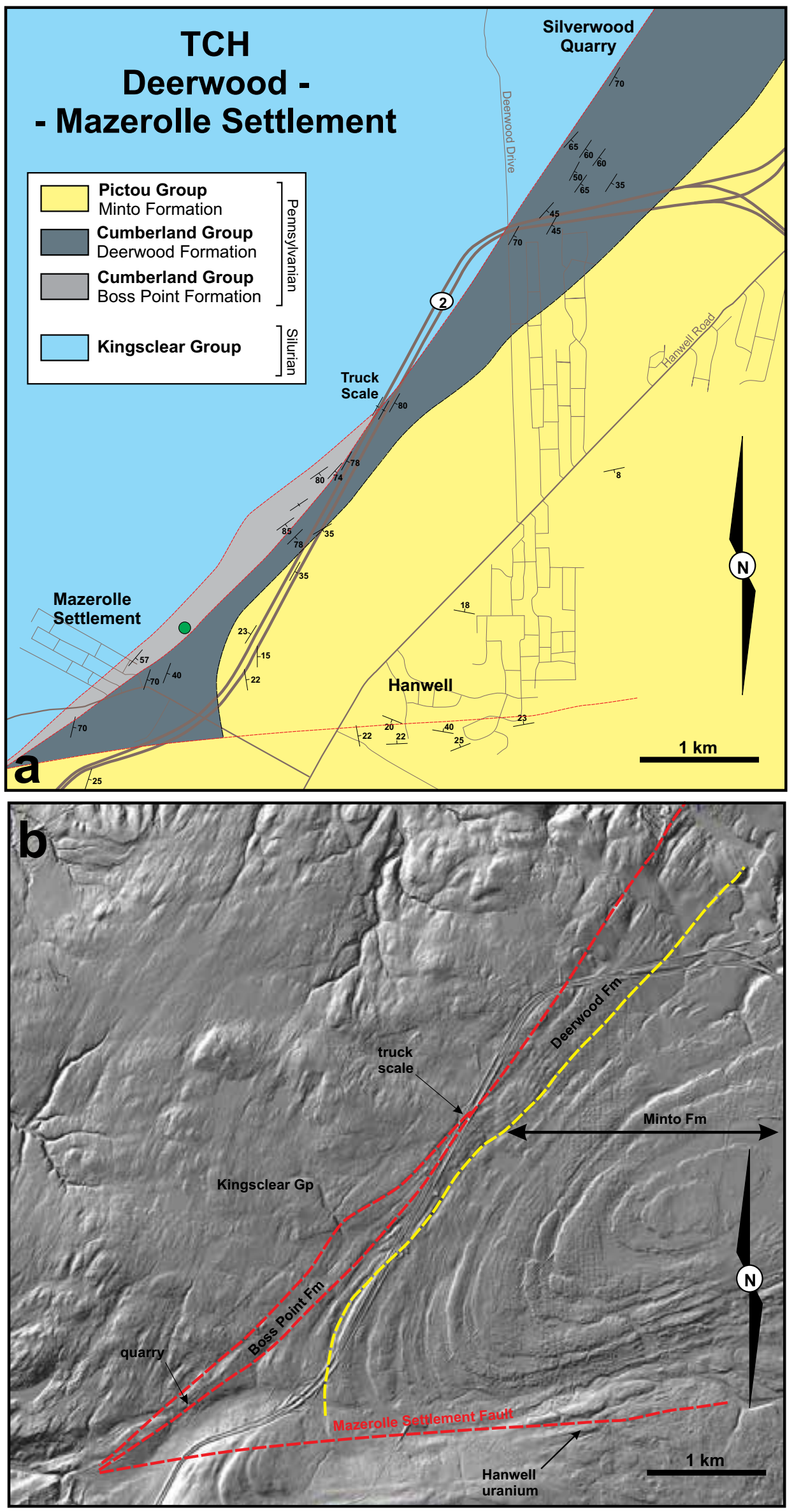
Kingsclear Group is marked by a scarp visible on LiDAR images. An exposure of these grey sandstone and shale rocks shows brecciated and folded grey siltstone. These folds have a near-vertical plunge and exhibit $\mathrm{Z}$-vergence, which implies right-lateral shear sense along axial planes parallel to the fault contact (Figs. 9a, b). These are the only clear kinematic indicators related to these splays of the main Fredericton Fault.

The eastern panel consists of grey-brown coarse feldspathic sandstone with conglomerate lenses and minor shale partings, with abundant logs and plant debris. This panel is continuous with the steeply dipping supposedly Minto Formation exposed along Highway 2 and is in faulted contact with the western panel as evidenced in a quarry exposure south of Mazerolle Settlement (Fig. 9c). Resampling this panel during the current study has produced miospores that are either ambiguously 'Westphalian' or typically Westphalian A, and no younger than Langsettian (Dolby 2016, Fig 8). This suggests that both panels consist of Cumberland Group rocks. This unit is herein named the Deerwood Formation (see Appendix).

LiDAR imagery displays a conspicuous difference in ground texture between these two steeply dipping panels and the unambiguous Minto Group exposed along Highway 2 to the east (Fig.8). The tabular 'slabby' conglomeratesandstone units making up the lower part of the Minto Formation along the Porcupine Mountain scarp and through the Hanwell area produce a ground texture that contrasts with that seen over the two steeply dipping panels, strongly suggesting an angular unconformity beneath the Minto Formation (Fig 8). The contact is not exposed, but along Highway 2, east of Mazerolle Settlement (Fig. 8), the Minto Formation outcrops show dips rarely greater than $20^{\circ}$ defining broad and open folds trending to the southwest and sub-parallel to the trend of the Fredericton Fault. The two steeply dipping panels containing possible Cumberland Group terminate against the Mazerolle Settlement Fault, and if they continue to the southwest must be buried beneath shallow-dipping Minto Formation.

More recent mapping suggests that the Fredericton Fault through this zone is not a single feature cutting Carboniferous rocks (Fig. 8). Instead the fault forms at least two splays separating Silurian Kingsclear Group from Cumberland Group and two units of Cumberland Group from each other: one of the panels containing rocks of the Boss Point Formation, the other the Deerwood Formation. The eastern panel continues northeast of the merger of two splays at the truck weigh-scale, and notably it is the eastern panel that contains the Silurian-Carboniferous (Deerwood Formation) paleosol contact. These splays merge into the fault seen during excavation at the Deerwood Drive overpass (Fig.8). To the northeast of this location the steeply dipping eastern panel continues toward the Saint John River and is in contact with the shallow-dipping Minto Formation through the poorly exposed ground to the northwest of Highway 2. The Minto Formation itself oversteps onto the eastern panel from the southeast, displaying some disturbance, notably open folding and minor upturning into the fault zone.

The stratigraphic relationship between the Boss Point and Deerwood formations cannot be ascertained here as they are always in fault-contact. Miospores imply they are both Langsettian and therefore included in the Cumberland Group (Figs 4, 8). The paleosol beneath the Deerwood Formation at its contact on Silurian basement suggests, but does not prove, it is the older unit.

The fault movement history revealed in the Deerwood to Mazerolle Settlement segment of the Fredericton Fault zone is all Pennsylvanian. Major movement, enough to turn an unconformity on end, and create two steeply dipping panels must be post-Langsettian and pre-Bolsovian. Minor post-Bolsovian movement then disturbed the Minto Formation that overstepped the fault zone itself.

\section{Douglas to Royal Road (Fig. 10)}

The most extensive outcrop of Shin Formation and the overlying Royal Road basalts together extend along the north side of the Saint John River between Douglas and the northwest part of Fredericton through Royal Road village (Fig. 10). Numerous quarries have been excavated in the basalts (Carlisle Road and Old City quarries are the largest) between Fredericton and Douglas. These excavations have exposed both the large flows with interflow sedimentary units and the overlying Pennsylvanian sandstone and conglomerate assigned to the Minto Formation (van de Poll 1973; St. Peter and Fyffe 2005). The eastern end of this belt around Royal Road village and the Nashwaaksis River valley defines a broad and open anticline cored by Silurian Kingsclear Group sandstone and shale currently exposed in the active Royal Road quarry (Fig. 10).

The Shin Formation consists of upward-fining conglomerate to siltstone/mudstone cycles, with caliche nodules and nodular layers, some of which are associated with paleosols and rootlet beds. The base of the sequence is a red-brown cobble to pebble conglomerate which is locally $20 \mathrm{~m}$ thick. The Royal Road basalt consists of two large flows, each exceeding $5 \mathrm{~m}$ thickness, with an interflow sequence of ash beds, lithic sandstone/siltstone, red-purple shale and chert resting on a 2 to $3 \mathrm{~m}$ thick paleosol developed on top of the lower flow(s). Several minor flows are present at the top of

Figure 8. (previous page) (a) Geological map of the area between Mazerolle Settlement and southwestern part of Fredericton (Silverwood) along the Trans-Canada Highway (Highway 2). Data from Park and Whitehead (2003), St. Peter and Fyffe (2005) and this study. Miospore data from Dolby (2016). (b) LiDAR image of the area in a. highlighting features such as the splays of the Fredericton Fault and the boundaries of the Minto, Boss Point and Deerwood formations (faults in red, other boundaries in yellow). LiDAR image from New Brunswick Department of Natural Resources (2016). 

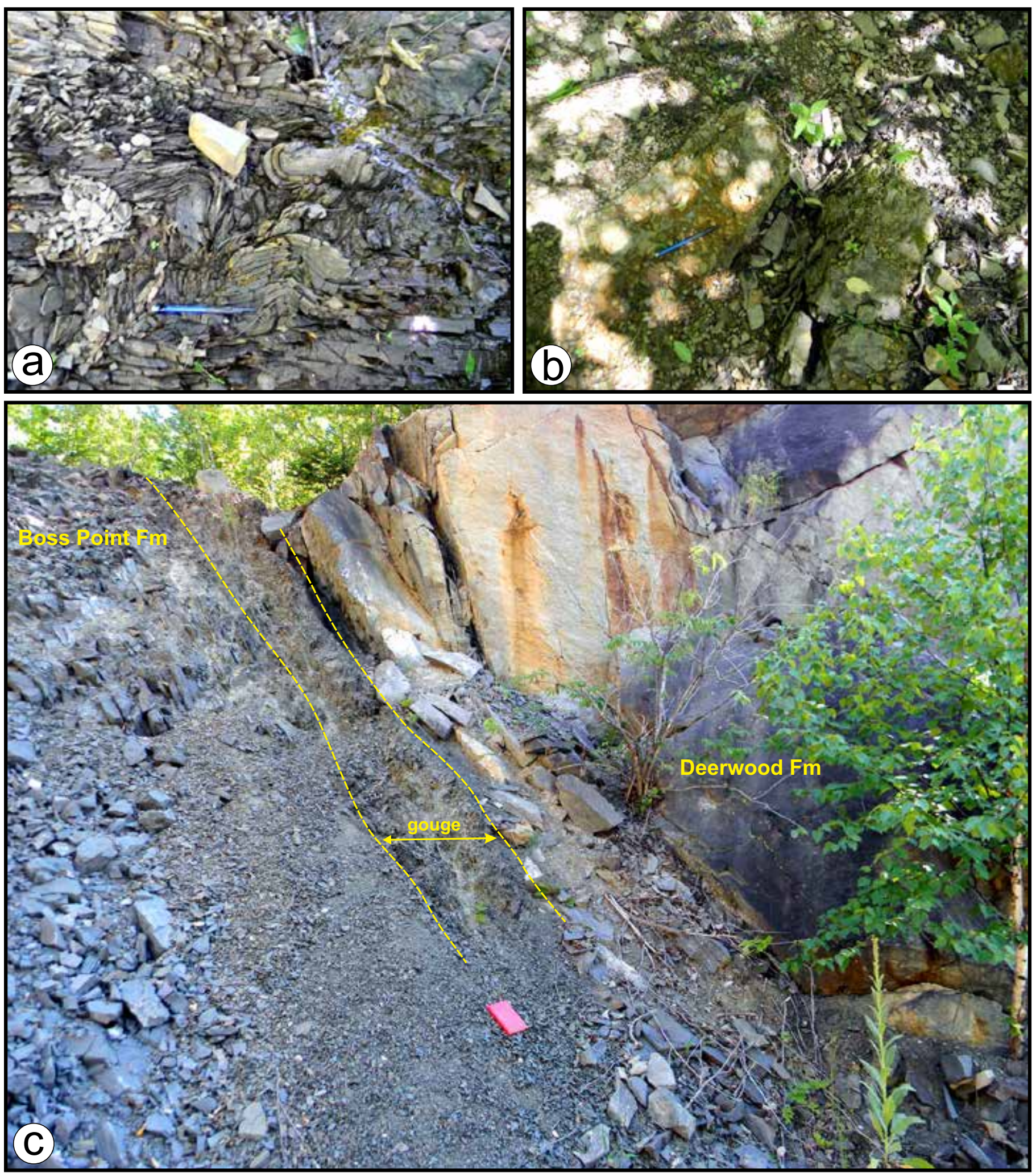

Figure 9. (a) Fault-damage in Silurian grey sandstone and shale (Kingsclear Group) immediately adjacent to the faulted contact with Boss Point Formation. Fold geometry suggests shear sense top-to-right (folds have near-vertical axes, ground surface is horizontal). Outcrop on ATV trail north of Highway 2 (GPS N 45.906 ${ }^{\circ} \mathrm{W} 066.788^{\circ}$ ). (b) Brecciated zone in Silurian grey sandstone, same location as a. (c) Boss Point Formation grey sandstone in faulted contact with brown-buff sandstone of Deerwood Formation in small quarry south of Mazerolle Settlement (see Fig. $8 \mathrm{~b}$ for location). Both units seem to have the same dip in this view, though strikes differ by $80^{\circ}$. (GPS N $45.880^{\circ} \mathrm{W} 066.823^{\circ}$ ). 


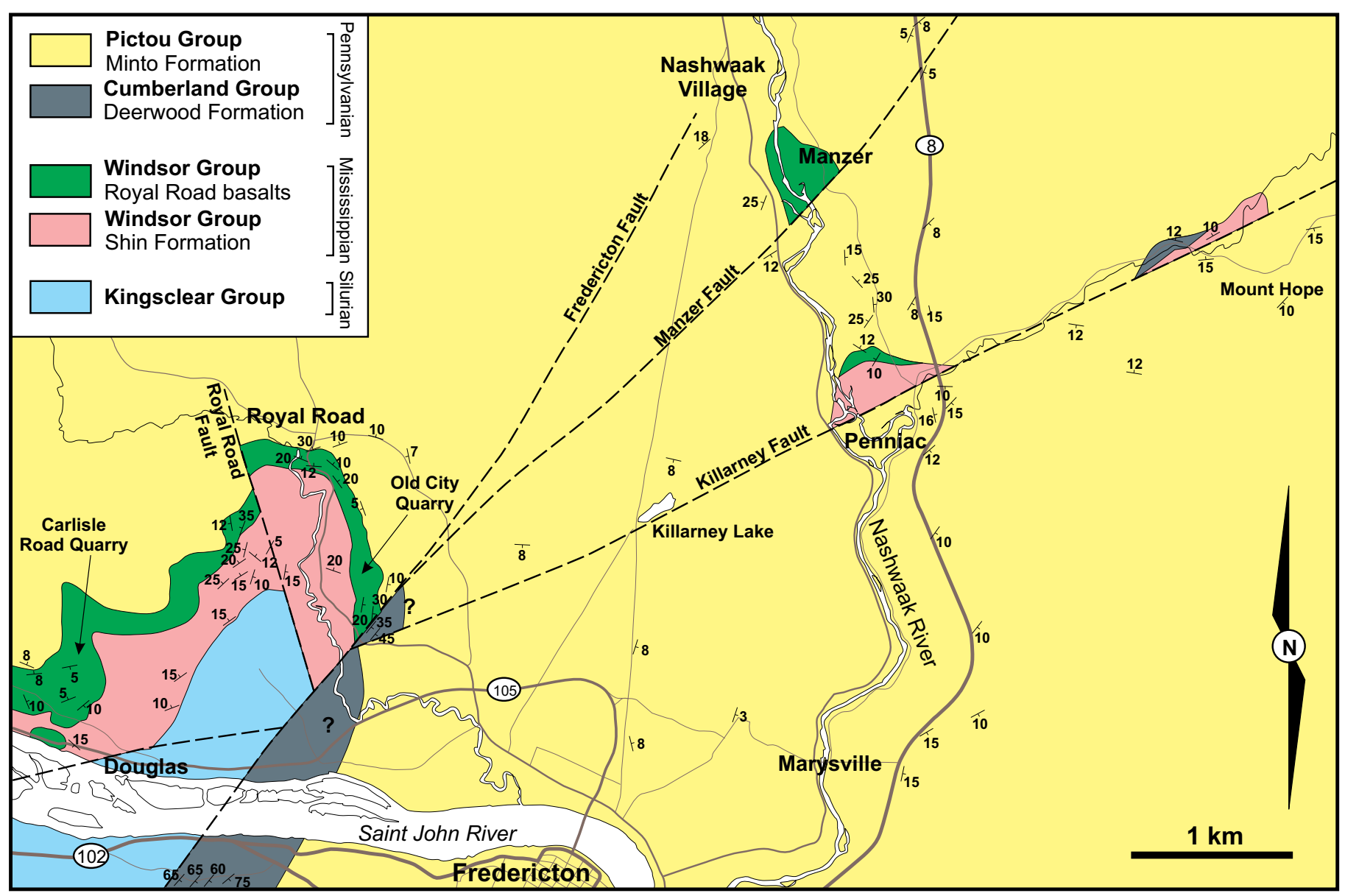

Figure 10. Geological map of the area northwest of Fredericton to Nashwaak Village and the Penniac River valley. Data from Smith and Fyffe (2006a), St. Peter and Fyffe (2005) and this study. Miospore data from Dolby (2016), Barss $(1969,1983)$ and Utting $(1996,2000)$. Durham Bridge is on Highway 8, $500 \mathrm{~m}$ north of this map.

the sequence in the Carlisle Road quarry, while only the two main flows are seen at Old City quarry (van de Poll 1973; Whitehead 2001, Figure 10). A diabase/microgabbro plug intruded into the Shin Formation at Currie Mountain is considered to represent a feeder to these flows. Near Douglas, a red shale-siltstone unit overlies all the flows and completes the sequence.

The Minto Formation overlies the Shin Formation with a marked unconformity. At the Carlisle Road quarry (Fig. 10) an irregular erosion surface is exposed which is immediately overlain by a cobble conglomerate with a coarse feldspathic sandstone matrix (Whitehead 2001). The same unconformity and conglomerate is observed in outcrops with lower quality exposure in the woods above the Old City quarry (Fig 10). Above this coarse conglomerate, the Minto Formation fines upward into coarse feldspathic and lithic sandstone with minor conglomeratic lenses. The sandstone is generally cross-bedded in sets exceeding a metre thick. Logs and plant debris are common.

Miospores typical of Langsettian (Westphalian A) stage were retrieved from this basal sequence south of the Old City Quarry (Barss 1983, Fig. 10), but subsequent remapping has revealed no break between this and the upper units that are more typically Minto Formation correlated with the area immediately to the north (Ball et al. 1981) and around Minto itself, where Bolsovian (Westphalian C) stage miospores are the norm (Hacquebard and Barss 1958). St. Peter and Fyffe (2005) assigned the entire sequence above the Royal Road basalt and unconformity to the Minto Formation (the interpretation preferred in this study), in contrast to earlier workers who identified a thin Cumberland Group interval (including the basal conglomerate) representing the Boss Point Formation (van de Poll 1973; Whitehead 2001).

At Carlisle Road quarry, the basalt flows are offset by a low-angle (dip $\sim 35^{\circ}$ toward $070^{\circ}$ ) reverse fault/thrust with a fold in its hanging wall (Fig. 11a). These structures are truncated by the base of the overlying Minto Formation. No such single fault structure is visible in the Royal Road basalt in the Old City quarry, instead, several sets of fractures with slickensides (typically coated in specular hematite and calcite) occur throughout (Figs. 11b, c). Slickenside lineations are generally shallowly plunging on surfaces that are typically steep to vertical and striking between 340 and $360^{\circ}$. None of these features are present in the overlying Minto Formation.

Along an access road at the south end of the Old City 

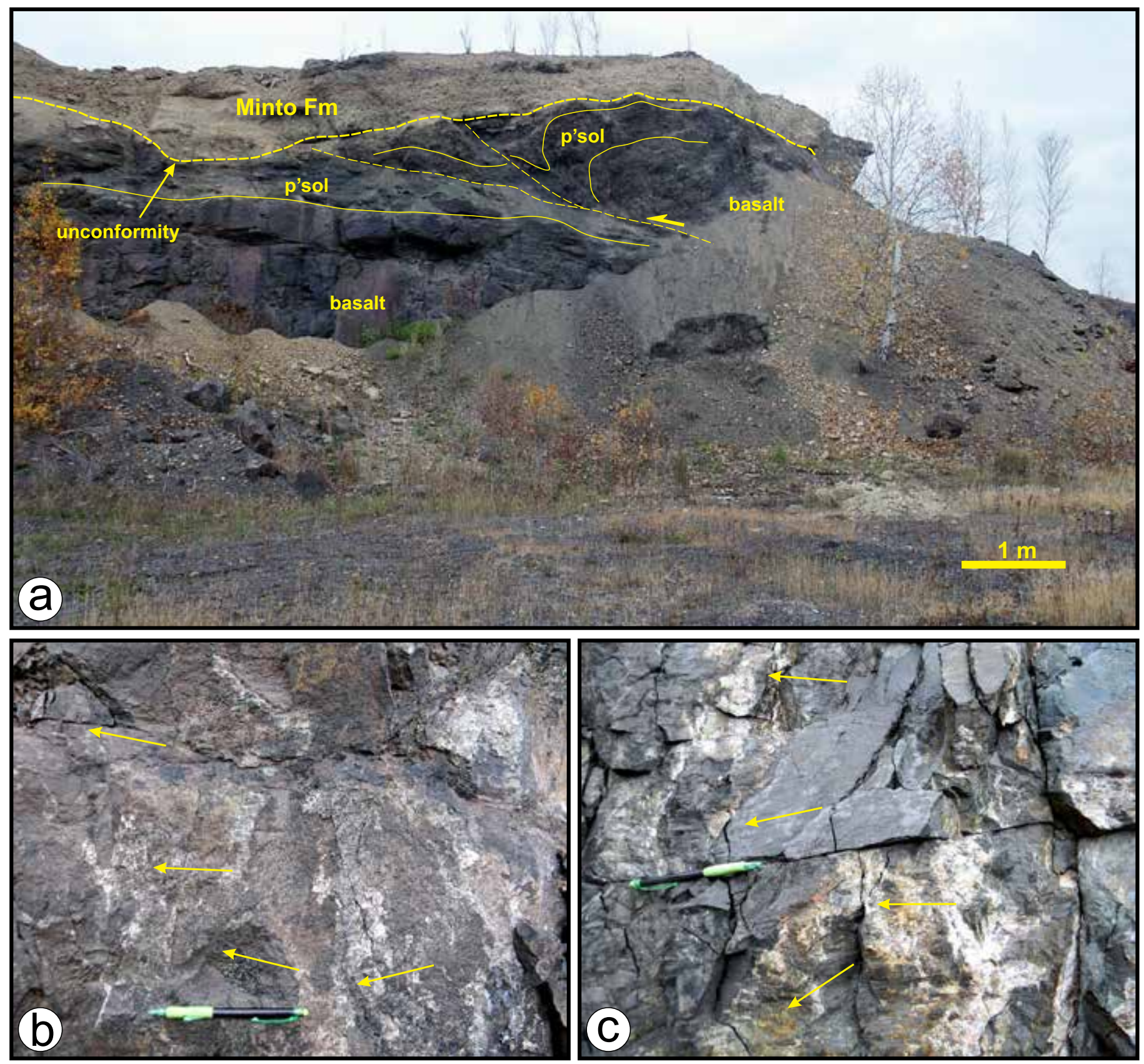

Figure 11. (a) Small thrust fault cutting Royal Road basalt, truncated by the unconformity beneath Minto Formation, Carlisle Road quarry (see Fig. 10). 'p'sol' is a paleosol layer above a basalt flow that merges upward into a bedded tufftuffaceous sandstone. The Minto Formation here is a pebble-cobble conglomerate with interbedded coarse-grained feldspathic sandstone (GPS N $45.992^{\circ} \mathrm{W} 066.755^{\circ}$ ). (b) Slickensides on fractures in basalt, Old City quarry (see Fig. 10). Slickensides are developed in quartz-calcite and show several orientations close to horizontal (GPS $\mathrm{N} 45.999^{\circ} \mathrm{W} 066.690^{\circ}$ ). (c) Slickensides on fractures in basalt, Old City quarry (Fig. 10). Slickensides on polished surfaces formed from calcite and specular hematite. Same location as $11 \mathrm{~b}$.

quarry (Fig. 10), there is an exposure of the faulted contact between the Royal Road basalt and coarse feldspathic sandstone with conglomerate lenses, shaly interbeds and abundant logs and plant debris (Fig. 12a). This unit dips steeply away from the contact, which follows the trend of the main Fredericton Fault south of the river. The dip of this unit varies from $35-55^{\circ} \mathrm{SE}$ in contrast to the Minto Formation on the high ground to the north above the quarries, where dips do not exceed $10^{\circ}$ and are generally $<5^{\circ}$ (Fig. 10). Miospore samples taken here did not yield anything distinctive (nonstage specific Westphalian, Dolby 2016). In contrast, the LiDAR imagery strongly suggests a continuation of Deerwood Formation in one of the steep-dipping fault-bounded panels along the Fredericton fault zone seen south of the Saint John 

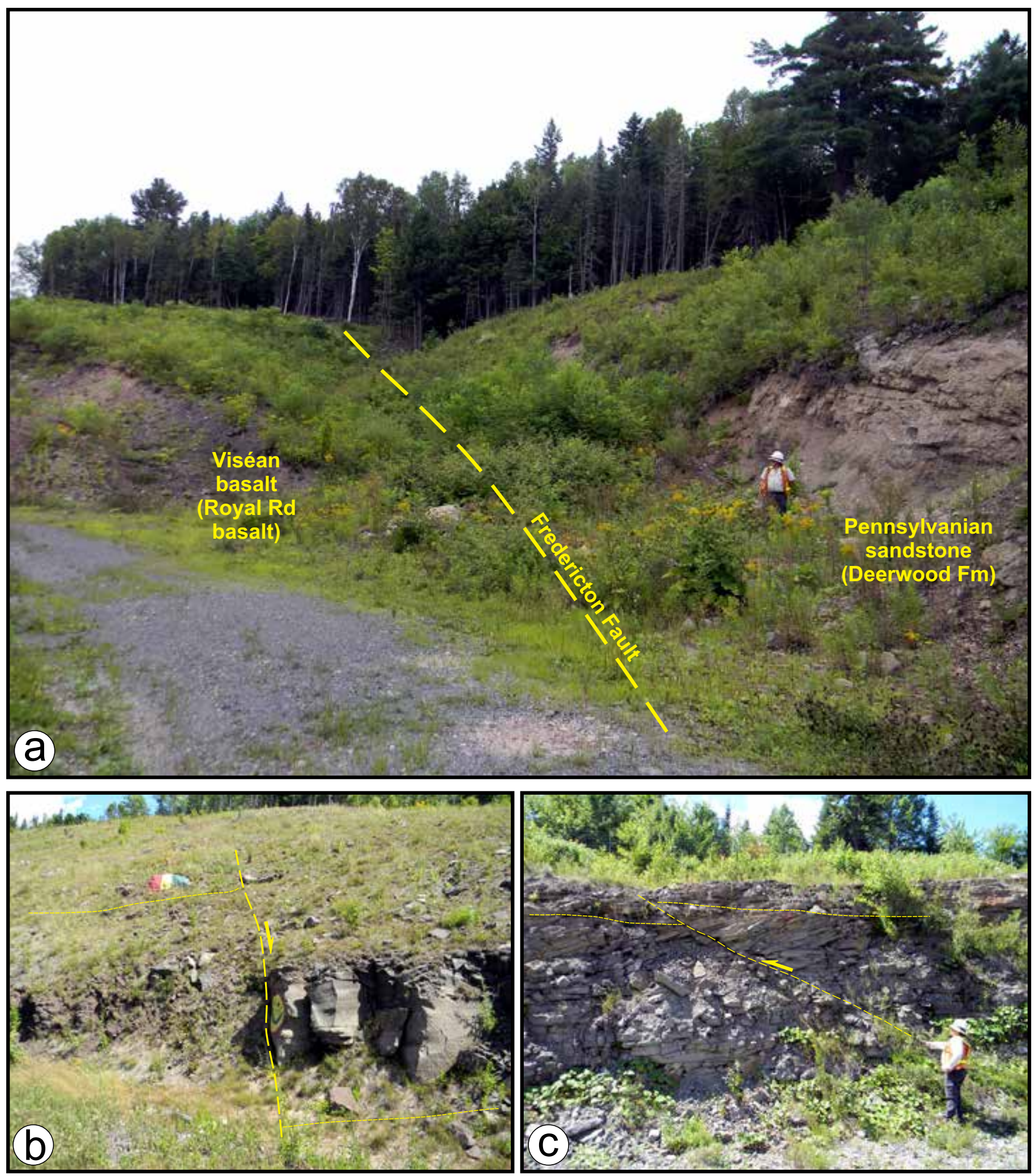

Figure 12. (a) Position of the Fredericton Fault marked by a gully between outcrops of Royal Road basalt and sandstone of the Deerwood Formation, Old City quarry (see Fig. 10) (GPS N $45.998^{\circ} \mathrm{W} 066.689^{\circ}$ ). (b) Small fault in Minto Formation (vertical dashed line) offsetting contact between coarse-grained grey-buff sandstone (above boundary) and red siltstoneshale (below boundary). View is looking east with right-side (south) down. Highway 8 south of Penniac (see Fig. 10) (GPS $\mathrm{N} 46.031^{\circ} \mathrm{W} 066.565^{\circ}$ ). (c) Small fault in Minto Formation, offsetting boundary between fore-sets and topsets in a coarsegrained buff-coloured sandstone. Offset is approximately $1 \mathrm{~m}$ along fault plane with right-side (north) up. View is looking west. Highway 8 north of Penniac (GPS N46.047 ${ }^{\circ} \mathrm{W} 066.571^{\circ}$ ). 
River, and that the shallow-dipping Minto Formation is draping both this and the basalts in the higher ground to the north (Fig. 10). The kinematics of this fault are unknown, though mapping suggests southeast-side down.

The shallow-dipping Minto Formation drape can be mapped from west of the Carlisle Road quarry, through Royal Road village, to the Old City quarry (Fig. 10), and within this belt there is only evidence of one major fault offset. This offset lies to the west of Royal Road along a fault zone that can be traced through the woods to the north of the new Royal Road quarry excavated into the Silurian rocks west of the Nashwaaksis River (Fig. 10). It is a NW-trending splay of the main Fredericton Fault. No fault-rocks are exposed, but mapping suggests this is a steep-dipping reverse fault with northeast-side up.

\section{Marysville to Durham Bridge (Fig. 10)}

The new Highway 8, the Marysville-Penniac by-pass, was completed in 2010 and exposed new outcrop, all in the Minto Formation as seen in road cuts from Marysville to Durham Bridge (Fig. 10). The Minto Formation throughout this area is generally a grey-brown to buff coloured coarse feldspathic and lithic sandstone with abundant conglomerate (cobble to pebble) lenses and larger tabular bodies. The sandstone ranges from coarse to medium, with the finer-grained examples showing extensive cross-bedding in sets exceeding a metre thick (up to $4 \mathrm{~m}$ ). Logs and plant debris are abundant, including complete Stigmaria roots in various non-growth positions. Other recognizable fragments include Lepidodendron, Sigillaria, Calamites and Cordiatales that are generally coalified. Thin coal seams and minor paleosols are also present. Reddened intervals are typically finer-grained sandstone and mudstone with nodular caliche layers, paleosols, rootlet beds and tree roots in growth positions, and intermittent thin coal seams. Overall the dip of the Minto Formation is shallow $\left(<10^{\circ}\right)$, though between Penniac, Manzer and Durham Bridge along Highway 8 dips up to $30^{\circ}$ define broad and open anticlinal and synclinal warps with roughly northward plunging axes (Fig. 10).

Two substantial faults, not exposed at the surface, have been identified as prominent NE-SW trending lineaments on LiDAR images which cross the route of Highway 8 in the Killarney Lake area (Fig. 10). The southern lineament, herein named the 'Killarney Lake Fault', follows the valley of Penniac River east of Highway 8, then crosses to the SW along the valley where Killarney Lake is situated, merging into the Fredericton Fault near the Old City quarry. The second feature, herein named the Manzer Fault, runs down the valley of the Durham River and crosses both Highway 8 and the Nashwaak River to the south of Durham Bridge village near Manzer. The Manzer Fault continues to the southwest and merges with the Fredericton Fault slightly north of the Killarney Lake Fault (Fig. 10). Both are substantial splays of the Fredericton Fault and displace Minto Formation.

In the Manzer area, a broad anticlinal warp in the Minto Formation to the north truncates against the surface trace of the fault, exposing in its core an inlier of Royal Road basalt (mapped by Dyer 1926, exposures no longer exist). This current study discovered a similar inlier immediately northwest of Penniac village exposing Shin Formation and Royal Road basalt (Fig. 10). A second inlier on the north side of the Killarney Lake Fault has been located along the Penniac River valley near Mount Hope, where a grey-green siltstone-shale unit, and red mudstone with caliche belonging to the Shin Formation occur beneath Minto Formation (Fig. 10).

In summary, the faults themselves are not exposed, and minor structures seen along the route of Highway 8 near Penniac and Durham Bridge include both normal (southside down) and reverse faults/thrusts (north-side up) with much the same trend as the large structures (Figs. 12b, c). Normal- or reverse-fault mechanism could be responsible for bringing Shin Formation and Royal Road basalt to surface given the incised valleys and practically horizontal Minto Formation cover known to be only 150 to $200 \mathrm{~m}$ thick (see Ball et al. 1981). The displacement involved need only be of the order of $50 \mathrm{~m}$.

\section{Minto and Hardwood Ridge (Fig. 13)}

Hardwood Ridge is a broad rise north of Minto township which marks the NW edge of the Minto coal field. The ridge itself is an inlier of the Hardwood Ridge basalt overlying a sequence of red conglomerate and sandstone of the Newcastle Creek Formation (Fig. 13). Using the borehole interpretations of Ball et al. (1981) as a guide, Smith and Fyffe (2006c) correlate the Newcastle Creek Formation with Shin Formation, and the Hardwood Ridge basalt with the Royal Road basalt and the basalt and trachytic rocks at Boiestown and near Stanley (Smith and Fyffe 2006b, Fig. 3). The 'basalts' range from true basalt to trachyandesite in composition (Fyffe and Barr 1986). Both Ball et al. (1981) and Wright (1939) refer to a 'trachytic' or 'rhyolitic' tuff forming a thin layer $(<1 \mathrm{~m})$ between the basalt and the Newcastle Creek Formation. This facilitated a correlation with the Cumberland Hill rhyolite/trachyte SE of Chipman (St. Peter 1997; Gray et al. 2010; Smith 2007), placing all the volcanic rocks at or near the top of the Shin Formation. An unpublished $\mathrm{U}-\mathrm{Pb}$ zircon age $(335 \pm 2 \mathrm{Ma})$ on the Cumberland Hill rhyolite (St. Peter, cited in Smith 2007) is largely the basis for considering these units to be Windsor Group time-equivalents (see MacFarlane et al. 2015). Recent work by Jutras et al. (2018) identifies two ash beds in the Shin Formation sequence, with the lower have a date identical within error.

Structure around the Minto coalfield and Hardwood Ridge inlier is rather simple, with the basalts lying in the core of a very broad and open anticlinal warp, which is paired with a similarly ill-defined synclinal warp to the southeast containing the coal field, and another anticlinal warp running through the valley of Salmon River, where a small inlier of Newcastle Creek Formation is exposed in the core (Fig. 13). Wright (1939) and Muller (1951) determined that these warps trended roughly NE-SW parallel to the long axis of 


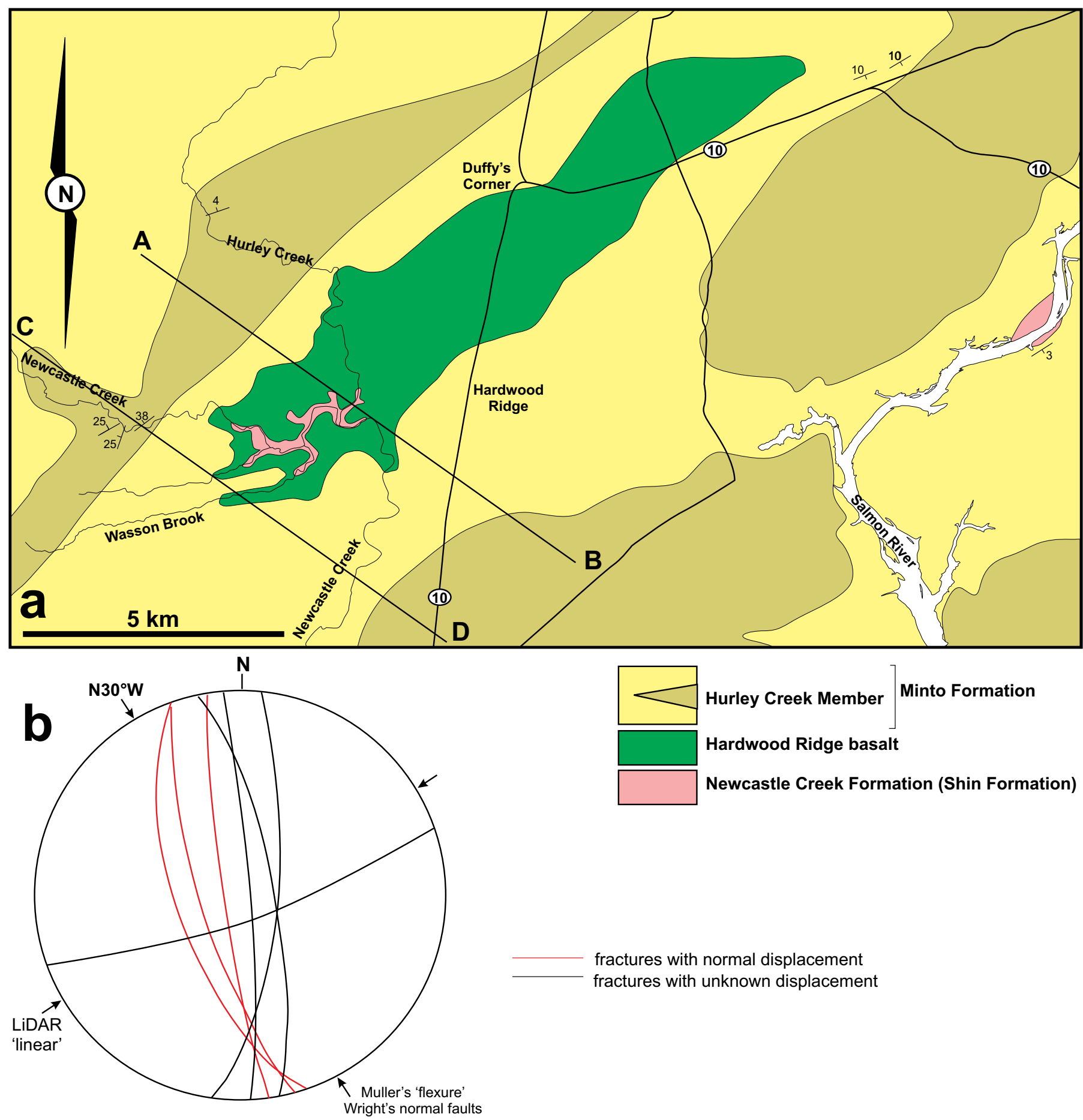

Figure 13. (a) Geological map of the area of Hardwood Ridge north of Minto, based on Smith and Fyffe (2006c) and Smith (2007). A-B and C-D show location of cross sections in Figure 14. Miospore data from Dolby (1998), Hacquebard and Barss (1958). (b) Stereographic projection of fractures with and without movement indicators from Newcastle Creek west of the basalt inlier. Equal area lower hemisphere projection. See Figure 14 for Wright and Muller references.

the Hardwood Ridge basalt outcrop. The presence of outcrop of Newcastle Creek Formation at the southwest end of the inlier reflects the deep incision of Newcastle Creek and its tributaries, the Wasson, Yeamans, and Hurley brooks in this location. Nevertheless, there is a slight northeastward plunge to the Hardwood Ridge anticlinal warp which can- not account for the termination of the basalt outcrop to the southwest.

The only dips steeper than average in the Minto Formation occur along the northwest side of the basalt inlier along Newcastle Creek, coincident with a conspicuous linear feature in both LiDAR and the magnetic anomaly map (New 
Brunswick Department of Natural Resources 2016; Thomas and Kiss 2005). Unfortunately, the high-resolution magnetic map does not cover the Fredericton area or extend to the southwest. Through this zone associated with the lineament, the dips of the Minto strata steepen to 35 and $40^{\circ}$ before abruptly shallowing out again to the northwest. This gives a distinctly asymmetric form to the anticlinal warp of the Hardwood Ridge inlier, a feature noted by Wright (1939) and Muller (1951) who included it in their detailed cross sections (Fig. 14). They accounted for this feature in different ways: Wright (1939) suggested a normal fault, with northwest- side down bounded the northwest edge of the inlier, while Muller (1951) considered the feature a genuinely asymmetric anticline but with the shape partly draped over a mass of basalt that was not continuous to either the northwest or southeast (Fig. 14).

Both Wright (1939) and Muller (1951) knew from old industry boreholes in the area of the Minto coalfield and outcrop of the Newcastle Creek Formation in Salmon River that the Hardwood Ridge basalt layer terminated to the southeast and east. Wright (1939) implied a continuation to the northwest, but Muller (1951) had the basalt layer wedge out to the northwest as well. The drilling program during the 1970s demonstrated Wright's (1939) basalt continuation to the northwest to be correct (Ball et al. 1981), however, there was no evidence for the normal fault along the northwest edge of the inlier. Muller's (1951) asymmetric anticline is consistent with the conclusion of the current study (Fig. 14), which leaves the issue of why the inlier terminates to the southwest.

Along Newcastle Creek west of the inlier (Fig. 13), the Minto Formation is cut by conspicuous fractures trending around 340 to $350^{\circ}$. On selected outcrops, the movement direction can be determined on these steep to vertical features to be dip-slip and west-side down. Muller (1951) noted 'warps' in the coal seams around Minto township with a similar trend, and Wright (1939) documented small normal faults in the Avon mine (southwest of Minto) with a similar trend with movement down to the west (Fig. 14).

The zone of steeper dips along the northwest edge of the Hardwood Ridge inlier and its coincidence with a LiDAR linear feature and a linear feature in the magnetic anomalies (Thomas and Kiss 2005) suggests a deeper root for this feature than the Pennsylvanian draping over an irregular basalt sub-layer (Muller 1951). Both Wright (1939) and Muller (1951) suggest basement faults and topographic irregularities play a roll, and with visible minor faults also affecting Minto Formation, a later structural effect seems likely. This study suggests a steep, southeast dipping basement fault lies toward the northwest edge of the inlier, which splays toward the surface and effectively becomes a set of 'blind' reverse faults generating the asymmetric anticline. Intriguingly, the broad anticline through the inlier, and the syncline to the southeast have trends that are oblique to this fault. The other oblique features are the small normal faults trending around $340-350^{\circ}$. The anticline-syncline trend suggests shortening along a northwest axis, and the normal faults suggest exten- sion close to E-W. If these relate to movement along the major fault beneath the inlier, then the movement is left-lateral strike-slip.

The proposed fault northwest of the Hardwood Ridge inlier expressed as a linear feature in the LiDAR image and magnetic anomaly maps can be traced in the former coverage south of Fredericton toward the Harvey area (Fig. 2). This would suggest the fault is a splay of the Fredericton Fault zone sharing a trend with the Killarney Lake Fault. This movement must be younger than the Bolsovian age of the Minto Formation.

\section{SYNTHESIS}

Timing of post-Acadian movement along various segments of Norumbega fault system, has proven difficult (see Ludman et al. 1999; Wang and Ludman 2002; West et al. 2008). The effects are clear, but in the absence of Carboniferous (or younger) rocks with a well-resolved stratigraphy the task has been challenging. In contrast, along the northernmost extension of the Norumbega fault system in southern New Brunswick, the Fredericton fault and related structures, interacted with a complex Carboniferous cover sequence. The relationships between faults associated with the Fredericton Fault and this partially resolved Carboniferous stratigraphy outlined above provide details of the post-Devonian tectonic evolution of this major Appalachian strike-slip fault system (summarized below and in Fig. 15).

The first late Paleozoic movement (Fig. 15a) seen along the Fredericton Fault appears associated with the red beds here called the Longs Creek Formation. These sediments are deformed along north-trending normal faults (down to the east) and then northeast-trending strike-slip faults with right-lateral strike-slip movement. All this movement predates deposition of the late Visean Shin Formation. A determination for the age of the Longs Creek Formation, like several red bed enclaves in fault-bound segments along the Norumbega fault system (Wang and Ludman 2002) is problematic. The presence of clasts of the Pokiok granite in the Longs Creek Formation suggests a middle Devonian maximum age, while the unconformity below the Shin Formation establishes a lower to middle Visean minimum age. The $\mathrm{N}-\mathrm{S}$ and NE-SW-trending faults that deform this unit must also have moved prior to Shin Formation deposition and be lower or middle Visean or older.

The second phase of Carboniferous movement (Fig. 15b) along the Fredericton Fault affects the Royal Road basalt and is truncated by the unconformity below the Minto Formation. The reverse fault/thrust seen in the Carlisle Road quarry and slickensides seen in the basalts of the Old City quarry suggest this movement was also right-lateral strikeslip. The timing of the fault movement must be constrained between eruption of the Royal Road basalt (late Visean, possibly Asbian-Brigantian) and pre-Minto Formation deposition (Bolsovian).

A phase of deformation that created the fault-bounded 

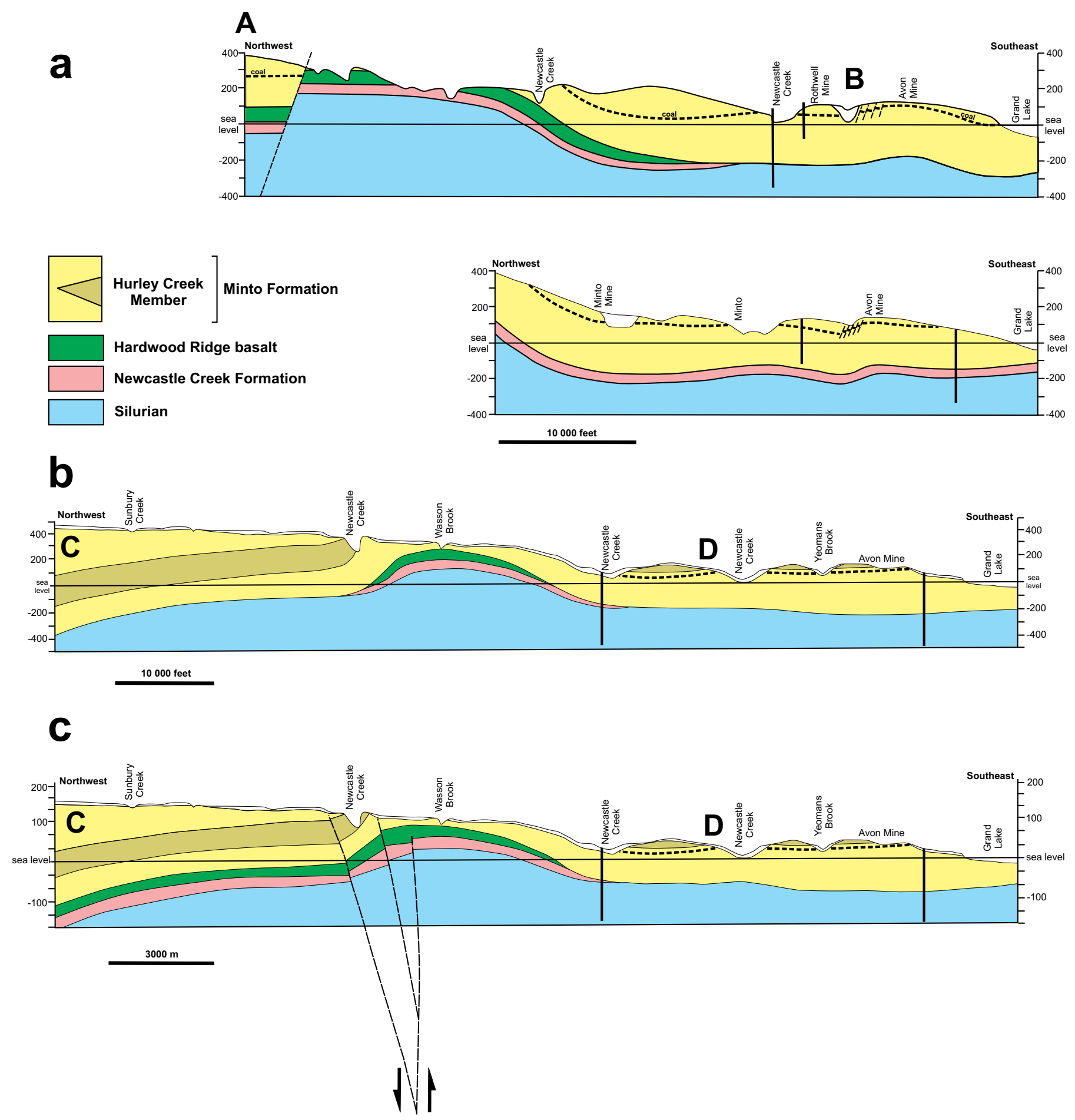

Figure 14. (a) Geological cross section $(5 \times$ vertical exaggeration) through the Hardwood Ridge basalt inlier along line A-B (see Figure 13a) and continued to the southeast into the Minto area, from Wright (1939). Stratigraphy is modified to follow Smith and Fyffe (2006c). The short section lies parallel and to the southwest of the longer section. (b) Geological cross section ( $5 \times$ vertical exaggeration) through the Hardwood Ridge basalt inlier along the line C-D (see Figure 13a) and continued to southeast into the Minto area, from Muller (1951). Stratigraphy is modified to follow Smith and Fyffe (2006c). (c) Geological cross section following Muller (1951, and maintaining 5X vertical exaggeration) incorporating data from this study and Ball et al. (1981), and using the stratigraphy from Smith and Fyffe (2006c) showing possible position of a deep fault (derived from LiDAR). Note metric scale on this cross section. 

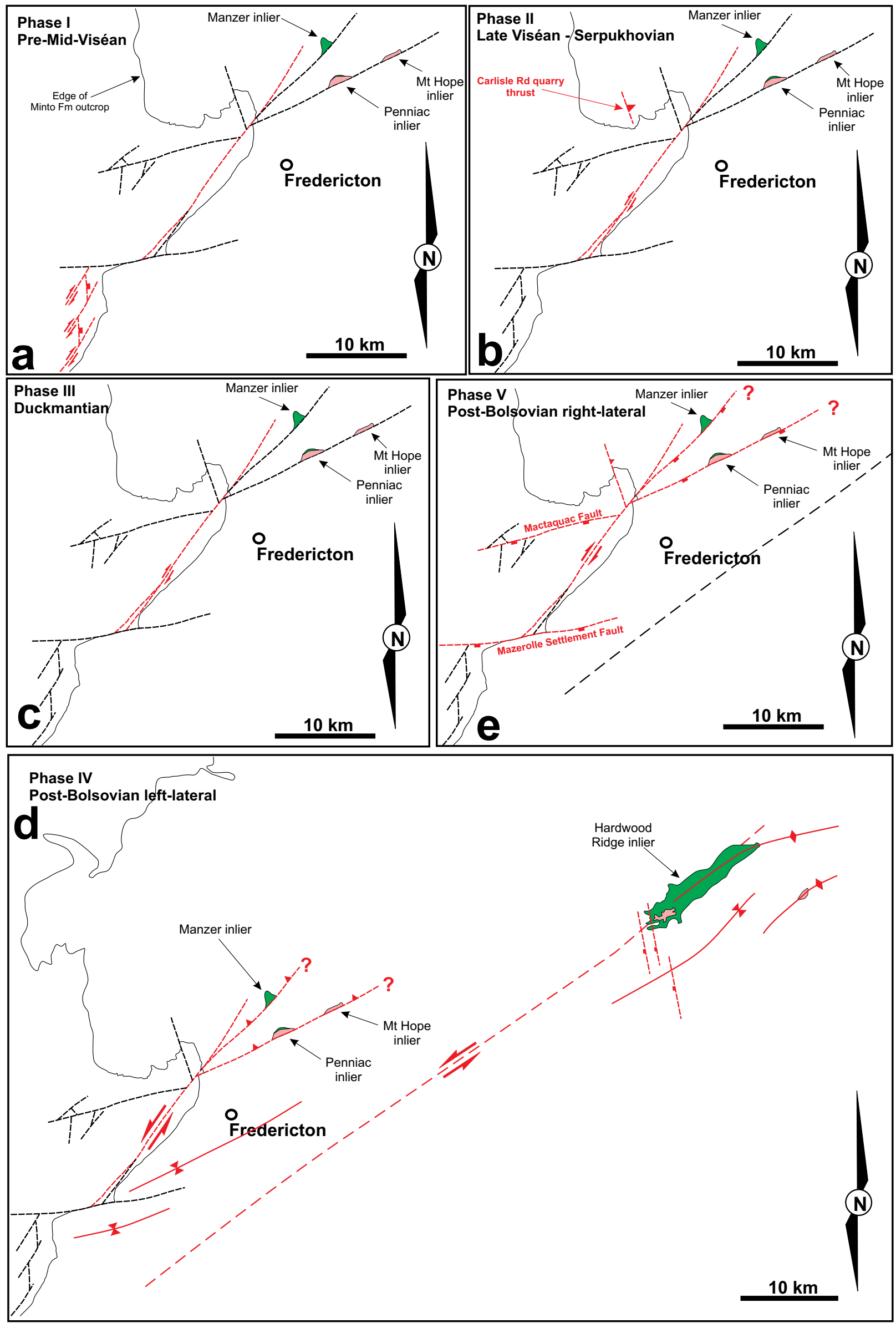
steeply dipping panels of Pennsylvanian rocks along the Fredericton fault (Fig. 15c) exposed along Highway 2 and near Mazerolle Settlement must also be pre-Bolsovian, but the presence of Cumberland Group (Langsettian) rocks here constrains the movement to the Duckmantian stage. Kinematic indicators in this zone are ambiguous though strongly favour strike-slip.

Elsewhere in southern New Brunswick, west of Saint John and at the eastern end of the Caledonian Highlands, there is clear evidence for a late Visean to Serpukhovian phase of fault motion and uplift creating an angular unconformity (Park et al. 2016). This is distinct to a major phase of movement of faults associated with salt movement during the Duckmantian stage (see Wilson et al. 2006; Craggs et al. 2015). Both these events are represented along the Fredericton Fault in this area.

Post-Minto Formation movements are apparent, but quite subtle. Creating the inliers at Manzer, Penniac and Hardwood Ridge would not require vertical movement of more than 50-100 m. Kinematic indicators are ambiguous. Around Penniac, reverse faults with north-side up and normal faults with south-side down share similar trends, and both could account for the inliers along the Penniac River valley. If these faults are related to the main Fredericton fault zone, then left-or right-lateral strike-slip motion, or a combination of both, could be responsible for the creation of these features (Fig. 15d). A left-lateral solution to the structures around the Hardwood Ridge inlier is highly suggestive, but whether this is a late movement confined to the fault below the inlier, or the system is a conjugate splay to the main Fredericton Fault cannot be resolved. As far as timing is concerned, post-Bolsovian is the only constraint.

One final group of post-Minto Formation faults are apparent (Fig. 15e), namely the E-W set that includes the Mazerolle Settlement Fault and those parallel to the Saint John River at Mactaquac. These consistently show south-side down in normal dip-slip movement. Given their obliquity to the main Fredericton Fault, they too could result from right-lateral strike-slip movement along the main fault. The age can only be constrained as post-Bolsovian.

\section{Comparisons along the Norumbega fault} system and elsewhere in New Brunswick

Along the Norumbega fault system in central and eastern Maine, associated with several minor fault-bounded basins of 'Carboniferous' red beds, Wang and Ludman (2002) determined evidence for three phases of movement creating brit- tle deformation (see also Ludman et al. 1999). Two phases were related to right-lateral strike-slip movement, and the latest third phase was resolved as left-lateral strike-slip (two have an oblique component). Given uncertainties in the ages of the affected red-beds, Wang and Ludman (2002) could only constrain the ages of these faulting episodes to be post-Devonian. They point out that low-temperature thermochronology studies along the southern portions of the Norumbega fault system (West and Roden-Tice 2003; West et al. 2008) indicate movement could be as young as Cretaceous. This study, focused about $60 \mathrm{~km}$ to the northeast of the Wang and Ludman (2002) study, identifies three phases of right-lateral movement along the Fredericton fault zone. Because of better age control on affected Carboniferous rocks in southern New Brunswick, significantly more detail can be provided on the timing of these episodes of displacement. In summary (see Fig. 15), these include from oldest to youngest: (1) the pre-Visean (strictly pre-middle Visean) event affecting the undated Longs Creek Formation confined in a small fault-bounded enclave along the fault zone, (2) a late Visean to Serpukhovian event affecting the Royal Road basalts with structures truncated by the subMinto Formation unconformity, and (3) a Duckmantian event.

Elsewhere in New Brunswick, and associated with other orogen-parallel strike-slip faults in Atlantic Canada, a post-Visean/pre-Pennsylvanian phase of right-lateral strikeslip motion is evident on the Kennebecasis and Clover Hill faults (Fig. 1, Waldron et al. 2015). A Duckmantian (latest Bashkirian to early Moscovian) event has been documented on the Penobsquis Fault within the Moncton basin (Wilson et al. 2006) and the Shepody-Wood Creek fault system along the NW edge of the Cumberland basin (Craggs et al. 2015). Interestingly, both these examples are associated with movement of the Windsor Group salt (see also Jutras et al. 2015), and whether this is salt tectonics alone, or strike-slip fault movement triggering salt tectonics is a source of debate (Jutras et al. 2015 preferring the former, Craggs et al. 2015 the latter). The existence of evidence for a Duckmantian right-lateral strike-slip event along the Fredericton Fault, where no salt deposits existed in Visean rocks, suggests strike-slip fault movement triggered salt movement in areas where evaporite deposits are important.

\section{CONCLUSIONS}

1. Displacements along the Fredericton fault zone, the

Figure 15. (previous page) Suggested fault movements through five phases from early Carboniferous to post-Bolsovian (see text for details). (a) Earliest phase of movement affecting Longs Creek Formation but not the younger Carboniferous units. (b) Late Visean-Serpukhovian phase of movement affecting the Royal Road basalt but not the Minto Formation. (c) Duckmantian phase of movement creating the vertical and steeply dipping panels of Cumberland Group rocks (Boss Point and Deerwood formations) exposed along Highway 2, but not affecting Minto Formation. (d) The post-Bolsovian left-lateral phase of movement also affecting the Minto area. (e) The post-Bolsovian right-lateral phase of movement. The east-west faults (especially the Mactaquac fault) appear to cut the folds associated with d. implying this is the last phase of movement. 
northern extension of the regionally extensive Norumbega fault system, post-dated the Acadian orogeny and were polyphase during Carboniferous time.

2. At least three periods of right-lateral strike-slip movement can be resolved using a refined Carboniferous stratigraphy:

a. Earlier than middle Visean, and depending on the age of the Longs Creek Formation, possibly as old as late Devonian.

b. A late Visean-Serpukhovian event is seen affecting the Royal Road basalts,

c. the third event can be constrained to Duckmantian time.

3. Post-Minto Formation (Bolsovian) movements can be resolved as related to both right-lateral and left-lateral strike-slip movement on the Fredericton Fault. The amount of movement may be as little as 50 to $100 \mathrm{~m}$, but because of near-horizontal bedding and subdued topography these movements have created the distinctive inliers along the Nashwaak and Penniac river valleys and Hardwood Ridge. The age of these movements is not well-constrained, other than being post-Bolsovian.

4. The Fredericton fault southwest of Fredericton contains fault-bounded enclaves of pre-middle Visean red beds (Longs Creek Formation), and newly-identified panels of Cumberland Group rocks.

\section{ACKNOWLEDGMENTS}

The authors acknowledge a considerable debt to Graham Dolby, whose miospore analyses resolved some of the stratigraphic problems in the Fredericton area. Discussions with Les Fyffe, Sue Johnson, and Kay Thorne helped clarify the results of this study. Dave West and an anonymous referee made useful suggestions to the submitted draft of this paper.

\section{REFERENCES}

Ball, F.D., Sullivan, R.M., and Peach, A.R. 1981. Carboniferous Drilling Project. New Brunswick Department of Natural Resources Report of Investigations 18, 109 p.

Barr, S.M., Brisebois, D., and Macdonald, A.S. 1985. Carboniferous volcanic rocks of the Magdalen Islands, Gulf of St. Lawrence. Canadian Journal of Earth Sciences, 22, pp. 1679-1688. https://doi.org/10.1139/e85-176

Barss M.S. 1969. Report to H. Van de Poll, New Brunswick Department of Mines, on samples submitted for age determination and comments on possible reworking of fossils. Map areas 21G/11, 21G/15, 21H/12, 21H/13, 21I/3, 21I/4, and 210/15, New Brunswick Department of Natural Resources. Geological Survey of Canada, Report 2-69 MSB, 5 p.

Barss, M.S. 1983. Reassessment of age assignment of two samples for L. Fyffe, New Brunswick Department of Natural Resources. Geological Survey of Canada, Report EPGS-PAL 25-83MSB, 1 p.

Bevier, M.L. and Whalen, J.B. 1990. U-Pb geochronology of
Silurian granites, Miramichi Terrane, New Brunswick. In Radiogenic Age and Isotopic Studies: Report 3, Geological Survey of Canada, Paper 89-2, pp. 93-100. https://doi. org/10.4095/129075

Brisebois, D. 1981. Lithostratigraphie des strates Permo-Carbonifères de l'archipel des Îles de la Madeleine. Ministère de l'Énergie et des Ressources du Québec, DPV-796.

Craggs, S., Keighley, D.G., Waldron, J.W.F., and Park, A.F. 2015. Salt tectonics in an intracontinental tectonic setting: Cumberland and Sackville basins, southern New Brunswick, Canada. Basin Research, 2015, pp. 1-18. https://doi. org/10.1111/bre. 12152

Dolby, G. 1998. Palynological analysis of outcrop samples from New Brunswick (Project 97.28). Unpublished report prepared for New Brunswick Department of Natural Resources and Energy, $10 \mathrm{p}$.

Dolby G. 2016, Palynological analysis of outcrop, well cuttings and core samples from New Brunswick, Project: 2016.02. Internal Report prepared for the New Brunswick Geological Surveys Branch, $22 \mathrm{p}$.

Durling, P. and Marillier, F. 1990. Structural trends and basement rock subdivisions in the western Gulf of St. Lawrence, northern Appalachians. Atlantic Geology, 26, pp. 7995. https://doi.org/10.4138/1694

Dyer, W.S. 1926. Minto coal basin. Geological Survey of Canada, Memoir 151, $42 \mathrm{p}$.

Fyffe, L.R. and Barr, S.M. 1986. Petrochemistry and tectonic significance of Carboniferous volcanic rocks in New Brunswick. Canadian Journal of Earth Sciences, 23, pp. 1243-1256. https://doi.org/10.1139/e86-121

Fyffe, L.R., Lutes, G.G., and St. Peter, C.J. 2005. Bedrock geology of the McAdam area (NTS 21 G/11), York County, New Brunswick. New Brunswick Department of Natural Resources; Minerals, Planning and Policy Division, Plate 2005-34, scale 1:50 000 .

Giles, P. 2008. Windsor Group (Late Mississippian) stratigraphy, Magdalen Islands, Quebec: a rare eastern Canadian record of late Viséan basaltic volcanism. Atlantic Geology, 44, pp. 167- 185. https://doi.org/10.4138/5932

Giles, P.S. and Utting, J. 1999. Maritimes Basin stratigraphy - Prince Edward Island and adjacent Gulf of St. Lawrence. Geological Survey of Canada, Open File 3732, 1 sheet. https://doi.org/10.4095/210469

Goldstein, A.G. 1989. Tectonic significance of multiple motions on terrane-bounding faults in the northern Appalachians. Geological Society of America Bulletin, 101, pp. 927-938. https://doi. org/10.1130/0016-7606(1989)101<0927:tsommo >2.3. $\underline{\mathrm{co} ; 2}$

Gray, T.R., Dostal, J., McLeod, M., Keppie, D., and Zhang, Y. 2010. Geochemistry of Carboniferous peralkaline felsic volcanic rocks, central New Brunswick, Canada: examination of uranium potential. Atlantic Geology, 46, pp. 173-184. https://doi.org/10.4138/atlgeol.2010.010

Hacquebard P.A. and Barss M.S. 1958. Progress Report on a spore study of the coal deposits in the Minto, Chipman and Beersville areas of New Brunswick, Canada Depart- 
ment of Mines and Technical Surveys, Geological Survey of Canada, $20 \mathrm{p}$.

Hacquebard, P.A. and Barss, M.S. 1970. Paleogeography and facies aspects of the Minto coal seam, New Brunswick, Canada. 6th International Congress on Carboniferous Stratigraphy and Geology, Sheffield 1967, Compte Rendu 3, pp. 861-872. https://doi.org/10.4095/106034

Johnson, S.C. and Jutras, P. 2004. A non-marine origin for massive carbonate horizons along the southern margin of the New Brunswick Platform: a follow-up study using carbon and oxygen isotopes. In Abstracts 2004, Exploration and Mining New Brunswick. Edited by S.A.A. Merlini, October 2004. New Brunswick Department of Natural Resources; Minerals, Policy and Planning Division; Information Circular, 2004-1, 17 p.

Jutras, P. and Prichonnet, G. 2005. Record of late Mississippian tectonics in the new Percé Group (Viséan) of eastern Gaspésie, Québec. Canadian Journal of Earth Sciences, 42, pp. 815-832. https://doi.org/10.1139/e05-024

Jutras, P., MacRae, R.A., and Utting, J. 2007. Visean tectonostratigraphy and basin architecture beneath the Pennsylvanian New Brunswick Platform of eastern Canada. Canadian Petroleum Geology Bulletin, 55, pp. $217-$ 236. https://doi.org/10.2113/gscpgbull.55.3.217

Jutras, P., McLeod, J., MacRae, R.A., and Utting, J. 2015. Complex interplay of faulting, glacioeustatic variations and halokinesis during deposition of upper Visean units over thick salt in the western Cumberland Basin of Atlantic Canada. Basin Research, 27, pp. 1-24. https://doi. org/10.1111/bre.12119

Jutras, P., Dostal, J., Kamo, S., and Matheson, Z. 2018. Tectonostratigraphic and petrogenetic setting of late Mississippian volcanism in eastern Canada. Canadian Journal of Earth Sciences, 55, pp. 356-372. https://doi.org/10.1139/ cjes-2017-0176

Kalkreuth, W., Marchioni, D., and Utting, J. 2000. Petrology, palynology, coal facies, and depositional environments of an Upper Carboniferous coal seam, Minto coalfield, New Brunswick, Canada. Canadian Journal of Earth Sciences, 37, pp. 1209-1228. https://doi.org/10.1139/cjes-37-91209

La Flèche, M.R., Camire, G., and Jenner, G.A. 1998. Geochemistry of post-Acadian, Carboniferous continental intraplate basalts from the Maritimes Basin, Magdalen Islands, Québec, Canada. Chemical Geology, 148, pp. 115136. https://doi.org/10.1016/s0009-2541(98)00002-3

Leonard, P.R.R., Lentz, D.R., and Pujol, M. 2006. Petrology, geochemistry, and $\mathrm{U}-\mathrm{Pb}$ (zircon) age of the quartz-feldspar porphyry dyke at the Lake George antimony mine, New Brunswick: implications for origin, emplacement process, and mineralization. Atlantic Geology, 42, pp. 13-29. https://doi.org/10.4138/2153

Ludman, A. and West, D.P. 1999. Preface. In Norumbega Fault System of the Northern Appalachians. Edited by A. Ludman and D. P. West. Geological Society of America Special Paper 331, pp v - xii. https://doi.org/10.1130/ spe331
Ludman, A., Lanzirotti, A., Lux, D., and Wang, C. 1999. Constraints on timing and displacement of multiple shearing in the Norumbega fault system, eastern Maine. In Norumbega Fault System of the Northern Appalachians. Edited by A. Ludman and D. P. West. Geological Society of America Special Paper 331, pp. 179-194. https://doi. org/10.1130/0-8137-2331-0.179

Ludman, A., Hopeck, J., and Berry, H.N. 2017. Provenance and paleogeography of post-Middle Ordovician, pre-Devonian sedimentary basins on the Gander composite terrane, eastern and east-central Maine: implications for Silurian tectonics in the northern Appalachians. Atlantic Geology, 53, pp. 63-85. https://doi.org/10.4138/atlgeol.2017.003

MacFarlane, C.R.M., Roulston, B.F., and Macdonald, C. 2015. Carboniferous volcanic rocks in the Picadilly Mine, Sussex, New Brunswick (abstract). Atlantic Geology, 51, pp. 124-125. https://doi.org/10.4138/atlgeol.2015.005

MacKenzie, G. 1946. Crocks Point Dam Site, (NTS 21 G/15), York County, New Brunswick. New Brunswick Department of Lands and Mines, Plate 1946-14, scale 1:63 360.

Martin, G.L. 2003. Gesner's Dream: the Triumphs and Trials of Early Mining in New Brunswick, Canadian Institute of Mining, Metallurgy and Petroleum, $328 \mathrm{p}$.

McLeod, M.J., Johnson, S.C., and Ruitenberg, A.A. 2005. Bedrock geology of the Hampstead area (NTS 21 G/09), Queens, Kings and Sunbury counties, New Brunswick. New Brunswick Department of Natural Resources; Minerals, Planning and Policy Division, Plate 2005-32, scale 1:50 000 .

Muller, J.E. 1951. Minto New Brunswick map, Geological Series with cross section and descriptive notes. Geological Survey of Canada, Department of Mines and Technical Surveys, Map 1003A, scale 1:63 360.

New Brunswick Department of Natural Resources. 2016. Regional remote sensing LiDAR survey, southwestern New Brunswick, acquired for New Brunswick Department of Natural Resources by Leading Edge Geomatics on June17th, 2016.

Park, A.F. and Whitehead, J. 2003. Structural transect through Silurian turbidites of the Fredericton Belt southwest of Fredericton, New Brunswick: the role of the Fredericton Fault in late Iapetus convergence. Atlantic Geology, 39, pp. 227-237. https://doi.org/10.4138/1183

Park, A.F., Hinds, S.J., Stimson, M.R., and Stringer, P. 2016. An upper Viséan - Serpukhovian (Mississippian) unconformity in southern New Brunswick and its significance.(Abstract). Atlantic Geology, 52, 89 p. https://doi. org/10.4138/atlgeol.2016.004

Smith, E.A. 2005. Bedrock geology of southwestern New Brunswick (NTS 21G, and part of 21B). New Brunswick Department of Natural Resources; Minerals, Policy and Planning Division, Plate 2005-33, scale 1:50 000.

Smith, E.A. 2007. Bedrock geology of the Chipman area (NTS 21 I/04), Sunbury and Queens Counties, New Brunswick. New Brunswick Department of Natural Resources; Minerals, Planning and Policy Division, Plate 
2007-50, scale 1:50 000.

Smith, E.A. and Fyffe, L.R. 2006a. Bedrock geology of the Burtts Corner area (NTS $21 \mathrm{~J} / 02$ ), York County, New Brunswick. New Brunswick Department of Natural Resources; Minerals, Planning and Policy Division, Plate 2006-3, scale 1:50 000.

Smith, E.A. and Fyffe, L.R. 2006b. Bedrock geology of the Napadogan area (NTS 21 J/07), York County, New Brunswick. New Brunswick Department of Natural Resources; Minerals, Planning and Policy Division, Plate 2006-8, scale 1:63 360.

Smith, E.A. and Fyffe, L.R. 2006c. Bedrock geology of the Minto area (NTS $21 \mathrm{~J} / 01$ ), York, Sunbury and Queens counties, New Brunswick. New Brunswick Department of Natural Resources; Minerals, Planning and Policy Division, Plate 2006-2, scale 1:63 360

St. Peter, C.J. 1997. Bedrock geology of Chipman - Canaan River map area (parts of NTS 21 I/04 and 21 H/13), Sunbury, Queens and Kings counties, New Brunswick. New Brunswick Department of Natural Resources and Energy, Mineral Resources, Plate 97-34, scale 1:20 000.

St. Peter, C.J. and Fyffe, L.R. 2005. Bedrock geology of the Fredericton area (NTS $21 \mathrm{G} / 15$ ), York and Sunbury counties, New Brunswick. New Brunswick Department of Natural Resources; Minerals, Planning and Policy Division, Plate 2005-38, scale 1:50 000.

St. Peter, C.J. and Johnson, S.C. 2009. Stratigraphy and structural history of the late Paleozoic Maritimes Basin in southeastern New Brunswick, Canada. New Brunswick Department of Natural Resources; Minerals, Policy and Planning Division, Memoir 3, 348 p.

Thomas, M.D. and Kiss, F. 2005. Geological interpretation of the 2004 Marrtown aeromagnetic survey, southeastern New Brunswick. Geological Survey of Canada, Open File 4953, New Brunswick Department of Natural Resources; Minerals, Policy and Planning Division, Plate 2005-21D, scale 1:1250 000. https://doi.org/10.4095/220708

Utting J. 1996, Palynological study of 22 samples from the Carboniferous of Burtts Corner, Central New Brunswick, submitted by W.H. Poole, GSC (OTTAWA) (NTS 21J/2, 21J/7 and 9), Internal report 1-JU-96 prepared for the New Brunswick Geological Surveys Branch, New Brunswick Department of Energy and Mineral Resources, 8 p.

Utting J. 2000. Palynological study of 23 samples from the Carboniferous of central New Brunswick; submitted by W.H. Poole, GSC (Ottawa) (NTS 21J/02 and 21J/08), Internal report 1-JU-00 prepared for the New Brunswick Geological Surveys Branch, New Brunswick Department of Energy and Mineral Resources, 13 p.

Van de Poll, H.W. 1972. Stratigraphy and economic geology of Carboniferous basins in the Maritime Provinces. Field Excursion A60. 24th International Geological Congress, Montréal, PQ, $96 \mathrm{p}$.

Van de Poll, H.W. 1973. Feasibility report concerning the hydrocarbon and coal potential of the Fredericton area. New Brunswick Department of Natural Resources, Mineral Resources Branch, Report 35 p.
Waldron, J.W.F., Rygel, M.C., Gibling, M.R., and Calder, J.H. 2013. Evaporite tectonics and the late Paleozoic stratigraphic development of the Cumberland Basin, Appalachians of Atlantic Canada. Geological Society of America Bulletin, 125, pp. 945-960. https://doi.org/10.1130/ b30718.1

Waldron, J.W.F., Barr, S.M., Park, A.F., White, C.E., and Hibbard, J. 2015. Late Paleozoic strike-slip faults in Maritime Canada and their role in the reconfiguration of the northern Appalachian orogeny. Tectonics, 34, pp. 1661-1684. https://doi.org/10.1002/2015tc003882

Wang, C. and Ludman, A. 2002. Evidence for post-Acadian through Alleghanian deformation in eastern Maine: multiple brittle reactivation of the Norumbega Fault system. Atlantic Geology, 38, pp. 37-52. https://doi. org/10.4138/1254

West, D. and Roden-Tice, M. 2003. Late Cretaceous reactivation of the Norumbega fault zone, Maine: evidence from apatite fission-track ages. Geology, 31, pp. 649-652. https://doi.org/10.1130/0091-7613(2003)031<0649:lcrot$\underline{\mathrm{n}>2.0 . \mathrm{co} ; 2}$

West, D.P., Roden-Tice, M.K., Potter, J.K., and Barnard, N.Q. 2008. Assessing the role of orogeny-parallel faulting in post-orogenic exhumation: low-temperature thermochronology across the Norumbega Fault system, Maine. Canadian Journal of Earth Sciences, 45, pp. 287-301. https://doi.org/10.1139/e07-073

Whalen, J.B. 1993. Geology, petrography and geochemistry of Appalachian granites in New Brunswick and Gaspésie, Québec. Geological Survey of Canada Bulletin 436, 124 p. https://doi.org/10.4095/183907

Whitehead, J. 2001. Geology of the Fredericton-Mactaquac dam area. In Guidebook to Field Trips in New Brunswick and western Maine. Edited by R.K. Pickerill and D. R. Lentz. New England Intercollegiate Geological Conference, Fredericton, New Brunswick, pp. A1-1 to A1-12. https://doi.org/10.26780/2017.001.0001

Wilson, P., White, J.C., and Roulston, B.V. 2006. Structural geology of the Penobsquis salt structure: late Bashkirian inversion tectonics in the Moncton Basin, New Brunswick, eastern Canada. Canadian Journal of Earth Sciences, 43, pp. 405-419. https://doi.org/10.1139/e05-116

Wright, W.J. 1939. Structure sections in Minto district, (NTS $21 \mathrm{~J} / 01$ ), Queens and Sunbury counties, New Brunswick. New Brunswick Department of Lands and Mines, Plate 1939-9, scale 1:63 360.

Editorial responsibility: David P. West, Jr.

\section{APPENDIX}

\section{Description of the Longs Creek Formation (new name)}

The Longs Creek Formation consists of coarse conglomerate with lesser breccia and is mostly red to red-brown in colour with minor amounts that are grey-green. Typical 
lithologies are red or red-brown matrix-supported conglomerate, red-brown feldspathic and lithic sandstone and red-brown siltstone/shale (Figs. 16a, b). Conglomerate clasts range from pebble to boulder grain size, the matrix being coarse feldspathic and lithic sandstone. Clasts consist of grey sandstone and grey slate from the Kingsclear Formation (Silurian), granite from the Pokiok batholith (early Devonian), vein quartz, and basalt, with very minor amounts of porphyritic felsic volcanic rock. Some of the grey-green conglomerate/breccia has a matrix made up entirely of coarse sparry calcite.

The Longs Creek Formation is in fault-contact with the Silurian Kingsclear Formation, but the presence of the latter as clasts in the conglomerates implies an unconformity. The Shin Formation overlies the Longs Creek Formation with an angular unconformity. The thickness of the Longs Creek Formation can only be estimated as there is no complete exposed section, and the effects of faulting and folding are apparent throughout the exposed sections, but is at least $50 \mathrm{~m}$.

A type section for the Longs Creek Formation is a large road cut along Highway 2 (Trans-Canada Highway) immediately west of the bridge over Longs Creek on the north side of the west-bound lane (GPS N $45.839^{\circ}$, W $066.900^{\circ}$ ). This consists of at least $50 \mathrm{~m}$ of section through typical redbrown conglomerate with minor coarse feldspathic redbrown sandstone and siltstone-shale partings. Neither base nor top of the sequence is visible.

Distribution of the Longs Creek Formation is restricted to a belt less than $1 \mathrm{~km}$ wide between the inlet of Longs Creek on the Mactaquac head-pond to just northeast of the village of Harvey. Most exposures are located between Newmarket and the Mactaquac head-pond, through the new sub-division development occurring between Highway 2 and the inlet.

Age of the Longs Creek Formation is not well-defined due to paucity of fossils and can only be constrained by the base of the overlying Shin Formation, which is most probably middle Visean (Holkerian-Asbian), and the presence of clasts of the lower to middle Devonian granites from the Pokiok batholith.

Depositional environment of the Longs Creek Formation is most probably a debris fan or channel-fill of topography on the Silurian surface. The very immature nature of the conglomerates indicates little working, and the removal of some sandstone matrix (possible elutriation) and large maximum clast size indicates high-energy water-flow.

The Longs Creek Formation was formerly included in the Shin Formation. The angular unconformity between the two only became apparent with new exposure in the area between Highway 2 and the inlet of Mactaquac head-pond, and the availability of LiDAR imagery.

\section{Description of the Deerwood Formation (new name)}

The Deerwood Formation consists of a grey-brown or buff-coloured coarse-grained to pebbly feldspathic and lithic sandstone with lenticular interbeds of pebble to cobble conglomerate and thin interbeds and partings of grey silt- stone and shale (Fig. 16c). Sandstone beds generally display cross-bedding with sets ranging from $0.2-2 \mathrm{~m}$ thick. Some conglomerate lenticles show channel cross-sectional forms. Partly coalified logs and woody debris are abundant, especially in the conglomerate lenses. Finer plant debris is ubiquitous. Conglomerate clasts consist of quartz (vein quartz), granite, grey sandstone and metamorphic rocks like quartzite and greenstone, with vein quartz dominant.

The Deerwood Formation is in faulted contact with the Boss Point Formation, and rests on a paleosol against Silurian Kingsclear Group. The upper contact with the younger Minto Formation is not exposed, but mapping and LiDAR images suggest the Minto Formation overlies this unit with angular unconformity.

Miospores recovered from siltstone-shale in the Deerwood Formation give a Westphalian assemblage no younger than Langsettian/Westphalian A (Dolby 2016).

A type section of the Deerwood Formation is designated along Highway 2 at the truck weigh scales SW of the Deerwood Drive overpass (GPS N $45.915^{\circ} \mathrm{W} 066.777^{\circ}$ ). The base of the unit is exposed on the northside of the westbound lane beside the exit from the scales. The bedding here is vertical, and continues through outcrops in the median of the highway through to the southside of the east-bound lane (GPS N $45.913^{\circ} \mathrm{W} 066.776^{\circ}$ ). This section, which does not expose the top of the formation, is at least $75 \mathrm{~m}$ thick.

Depositional environment of the Deerwood Formation is most probably a braid-plain combining relatively high-energy flow and high sediment-loaded streams, with modest channels. The sediment load included much woody debris including substantial logs and root-masses.

\section{The local Boss Point Formation}

The local Boss Point Formation has caused problems since the 1950s, when the correlation with the main outcrop area of this unit NE and east of Sussex was purely lithostratigraphic. Some miospore data collected in the 1970s and 1980s (see van de Poll 1973, Barss 1983) defined Westphalian A assemblages, including samples from immediately NE of Mazerolle Settlement in the partly indurated grey sandstone-shale unit described here as 'Boss Point Formation'. Miospores sampled in this study confirm a Westphalian A age (no younger than Langsettian, Dolby 2016). As this lithology matches Boss Point Formation under both biostratigraphic and lithostratigraphic criteria, we recommend the name be revived for this unit, rather than erect a new local name.

A reference section for this local Boss Point Formation would be road-cuts in Mazerolle Settlement (GPS N $45.887^{\circ}$ $\mathrm{W} 066.814^{\circ}$ ) on the corner of Madonna Drive and Snowball Drive. These cuttings expose grey coarse- to mediumgrained sandstone with grey shaly partings and minor quartz pebble conglomerate lenses. The sandstone here is almost completely indurated and unusually hard compared to most of the local Carboniferous sandstone. It has been compared to the grey sandstone of the Silurian Kingsclear 

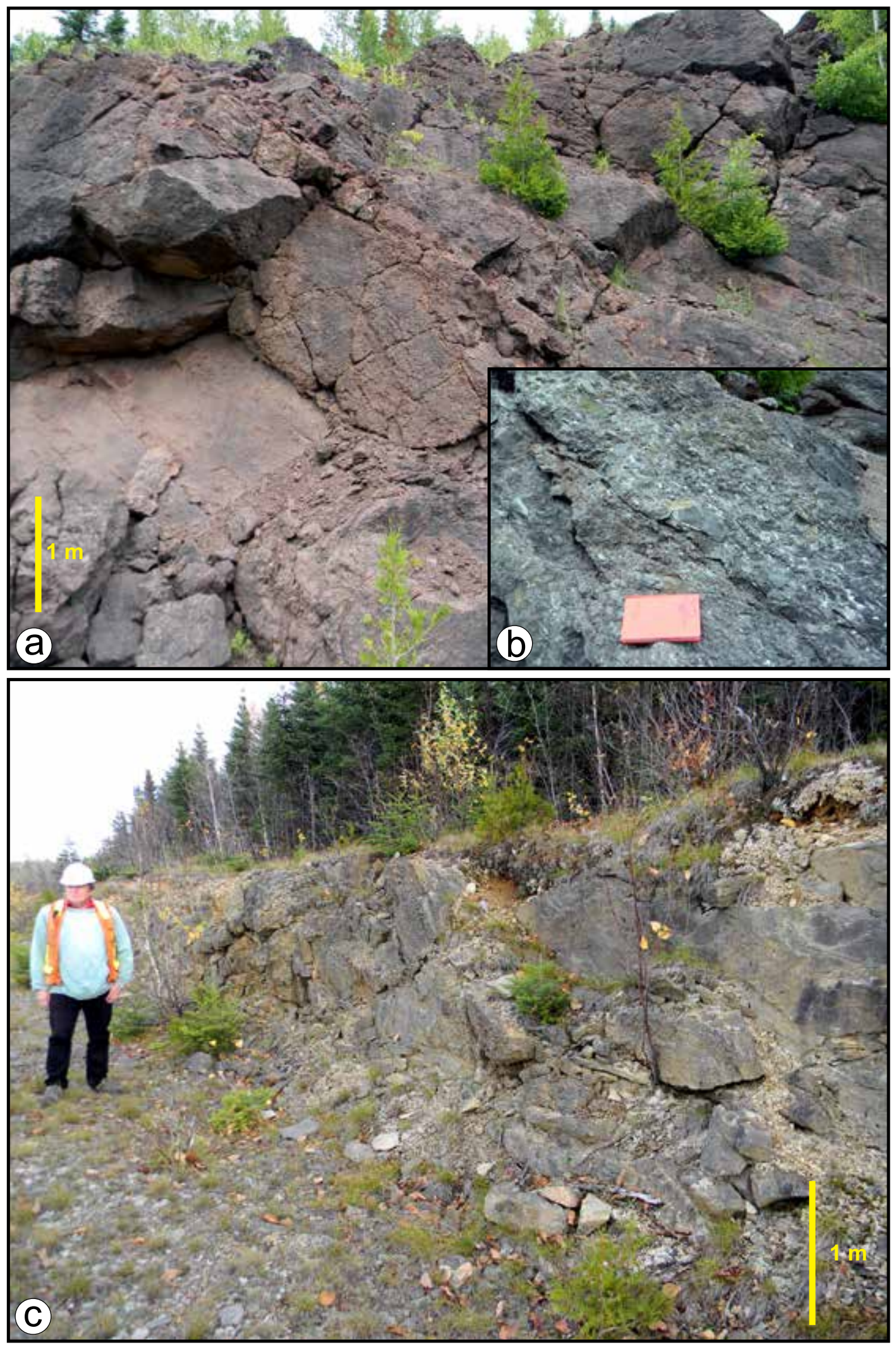

Figure 16. (a) Longs Creek Formation in the type section in a road-cut on the Trans-Canada Highway (northside of westbound lane, GPS N $45.839^{\circ}$, W $066.900^{\circ}$ ). (b) Greenish variant of the Longs Creek Formation with some sparry calcite cement and conspicuous clasts of dark grey-green sandstone from the Kingsclear Group, same location as Figure 16a. (c) Outcrop of the Deerwood Formation consisting of lenticular conglomerate bodies in coarse-grained feldspathic sandstone. Bedding is vertical. Type section on Trans-Canada Highway (south side of east-bound lane, GPS N $45.913^{\circ} \mathrm{W} 066.776^{\circ}$ ). 
Group with which it may be confused. However, bedding planes in the medium-grained sandstone are conspicuously micaceous and carry sparse plant debris, and the shaly layers do not carry a slaty cleavage (in contrast to the grey shale in the Kingsclear Group which always carries a slaty cleavage). This unit is always in faulted contact with the Deerwood Formation (Fig. 9c) and the Silurian Kingsclear Group, and a thickness estimate is not possible. 